\title{
Investigation of the Initial Fragmentation of Oligodeoxynucleotides in a Quadrupole Ion Trap: Charge Level-Related Base Loss
}

\author{
Su Pan, Kathryn Verhoeven, and Jeehiun K. Lee \\ Department of Chemistry and Chemical Biology, Rutgers, The State University of New Jersey, Piscataway, \\ New Jersey, USA
}

The charge state distribution and CID fragmentation of two series of deprotonated oligodeoxynucleotide (ODN) 9-mers (5'-GGTTXTTGG-3' and 5'-CCAAYAACC-3', X/Y = G, C, A, or T) have been studied in detail in an ion trap in an effort to understand the intrinsic properties of DNA in vacuo. The distribution of charge states $(-2$ to -6$)$ is similar for both the X-and Y-series, with the most abundant being the -4 charge state. The T-rich $X$-series prefers higher charge states $(-6$ and -5$)$ than does the Y-series. Calculations show that phosphate groups located nearest a thymine are more acidic than those near an adenine, cytosine, or guanine, thus explaining why the X-series prefers higher charge states. We use the term "charge level" to define the ratio of the charge state to the total number of phosphate groups present in the ODN. We find, consistent with previous studies, that the initial step of fragmentation is loss of nucleobase either as an anion or as a neutral. We observe the former for ODNs with charge levels greater than $50 \%$ and the latter for ODNs with charge levels below $50 \%$. The overall anionic base loss follows the trend $\mathrm{A}^{-} \gg \mathrm{G}^{-} \approx \mathrm{T}^{-}>\mathrm{C}^{-}$; electrostatic potential calculations indicate that this trend follows delocalization of electron density for each anion, with $\mathrm{A}^{-}$being the most stabilized through delocalization. For neutral base loss, thymine (TH) is rarely cleaved, while the preferences for AH, GH, and CH loss vary. Proton affinity (PA) calculations show that a nearby negatively charged phosphate enhances the PA of proximally located nucleobases; this PA enhancement probably plays a role in promoting neutral base loss. The trends differ by charge level. At a charge level of 37.5\% ( -3 charge state), AH loss is preferred over $\mathrm{CH}$ and GH loss, regardless of sequence. However, at a charge level of $25 \%$ ( -2 charge state), the terminal bases are preferentially lost over the internal bases, regardless of identity. By reconstructing the ODN sequences from structurally informative (a-BH) and w ions, we are able to identify the charge locations for the -3 and -2 charge states. For the -3 charge state, one charge resides on each "most terminal" phosphate, with the third being in the middle. For the -2 charge state, each charge resides on the penultimate phosphate groups. We compare our data to earlier experiments in an effort to generalize trends. (J Am Soc Mass Spectrom 2005, 16, 1853-1865) (C) 2005 American Society for Mass Spectrometry

$\mathrm{T}$ The examination of the fragmentation of DNA in the gas phase has importance in both a fundamental sense-to understand the intrinsic properties of oligodeoxynucleotides (ODNs) - and also in an applied sense, to aid in the development of mass spectrometric-based methods for nucleotide sequencing and identification.

The dissociation of deprotonated ODNs has been extensively investigated by mass spectrometry (MS) coupled with soft ionization methods such as electrospray (ESI) and matrix-assisted laser desorption ionization (MALDI) [1-14]. It is known that the first step in the dissociation of deprotonated ODNs is loss of a

Published online September 28, 2005

Address reprint requests to Dr. J. K. Lee, Department of Chemistry and Chemical Biology, Rutgers, The State University of New Jersey, 610 Taylor Road, Piscataway, NJ 08854, USA. E-mail: jklee@rutchem.rutgers.edu. nucleobase, either in a neutral $(\mathrm{BH})$ or deprotonated $\left(\mathrm{B}^{-}\right)$form $[1,2,15]$. Loss of $\mathrm{BH}$ or $\mathrm{B}^{-}$is followed by cleavage of the phosphodiester bond at the $3^{\prime} \mathrm{C}-\mathrm{O}$ position of the deoxyribose from which the initial base was lost. We will refer to the ions thus produced by the well-accepted McLuckey nomenclature: (a-base) and w type ions (Figure 1) [1].

The loss of a nucleobase as a deprotonated anion or as a neutral is dependent on the identity of the base and the charge state of the parent ODN ion $[2,4,8,16]$. The higher charge states favor $\mathrm{B}^{-}$loss while lower charge states favor $\mathrm{BH}$ loss. There have not been many studies on anionic base cleavage; but for strands greater than two mers, the order of preference in terms of loss appears to be $\mathrm{A}^{-}>\mathrm{T}^{-}>\mathrm{G}^{-}, \mathrm{C}^{-}$(where $\mathrm{A}=$ adenine, $\mathrm{T}=$ thymine, $\mathrm{G}=$ guanine, and $\mathrm{C}=$ cytosine, Figure 1 ) $[1,16]$.

There have been comparatively more studies focus- 

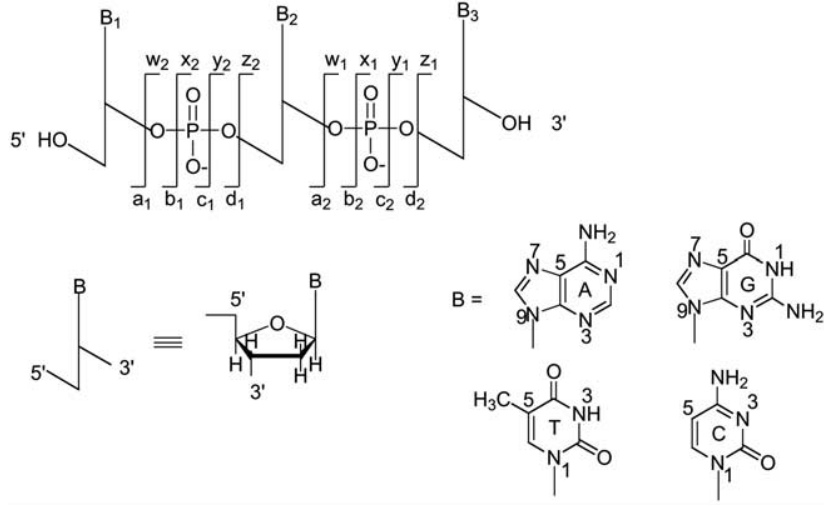

Figure 1. Oligodeoxynucleotide fragmentation pathways, adapted ${ }^{\circ}$ from ${ }^{\circ} \mathrm{McLuckey}^{\circ} \mathrm{et}^{\circ}$ al. $;^{\circ} \mathrm{B}^{\circ}={ }^{\circ}$ base $^{\circ}={ }^{\circ} \mathrm{A},{ }^{\circ} \mathrm{G},{ }^{\circ} \mathrm{C},{ }^{\circ} \mathrm{T}$.

ing on neutral base loss, with the preference of base loss appearing to be highly variable, depending on sequence, charge state, and even the instrumentation method [9, 13, 16-18]. Many mechanisms have been proposed to explain the typically observed $\mathrm{BH}$ loss, which is normally followed by backbone fragmentation [13]. The proposals can be divided into two general mechanisms, which differ by when proton transfer occurs. One possibility is loss of the deprotonated nucleobase followed by proton abstraction from the ODN so that the nucleobase is ultimately lost as a neutral. The second possibility is loss of the neutral nucleobase involving proton transfer before, or concomitant with, the nucleobase cleavage.

The apparent lack of agreement among the reported trends is not fully understood. For example, Wan and Gross reported the propensity to form (a-BH) ions follows the order of $\mathrm{GH}>\mathrm{CH} \approx \mathrm{AH} \gg \mathrm{TH}$ in doubly charged T-rich 8-mers (5'-TTTXYTTT-3', X/Y = G, C, A, or T) [13]. Smith and coworkers examined the neutral base loss from a series of multiply charged 12-mers ( -3 , -4 , and -5 charge states) [17]. The same trend (GH $>$ $\mathrm{CH} \approx \mathrm{AH} \gg \mathrm{TH}$ ) as that reported by Gross was observed for the -3 charge state, but different trends were noted at the $-4(\mathrm{AH}>\mathrm{CH} \approx \mathrm{GH} \gg \mathrm{TH})$ and at the $-5(\mathrm{AH} \gg \mathrm{CH}>\mathrm{GH} \gg \mathrm{TH})$ charge states. For neutral base loss from large multiply charged oligonucleotide ions (up to 100-mers), McLafferty and coworkers reported a general trend of $\mathrm{AH}>\mathrm{CH} \approx \mathrm{GH} \gg \mathrm{TH}$ [18]. Recently, Daneshfar and Klassen measured Arrhenius activation parameters $\left(E_{a}\right.$ and $\left.A\right)$ for the loss of neutral nucleobases $(\mathrm{AH}, \mathrm{GH}$, and $\mathrm{CH})$ from a series of doubly deprotonated ODN 10-mers of the type $\mathrm{XT}_{9}$, $T_{9} X$, and $T_{5} X_{4}$, where $X=A, G$, and $C$, using the blackbody infrared radiative dissociation (BIRD) technique [9]. The ${ }^{\circ}$ kinetics ${ }^{\circ}$ or ${ }^{\circ}$ loss ${ }^{\circ}{ }^{\circ}$ the ${ }^{\circ}$ temperature ${ }^{\circ}$ range they investigated $\left(120-190^{\circ} \mathrm{C}\right)$ indicate that $\mathrm{AH}$ and $\mathrm{GH}$ are lost at comparable rates while $\mathrm{CH}$ is lost about 100 times more slowly. These authors suggest that the lack of agreement among the reported trends in base reactivity may be attributed to the structural complexity and varying internal energy distributions of the different ODNs.

Consequently, the main issue with ODN fragmentation is the lack of understanding of the factors controlling the preferences for base loss, both from highly charged and less highly charged ODNs. To try to lend insight into these outstanding issues, we chose a set of nonselfcomplementary nonadeoxyribonucleoside octaphosphates, 5'-d(GGTTXTTGG)-3' and ${ }^{\circ} 5^{\prime}$-d(CCAAYAACC)-3', 'where $\mathrm{X}^{\circ}$ and ${ }^{\circ} \mathrm{Y}^{\circ}$ are $^{\circ} \mathrm{G},{ }^{\circ} \mathrm{C},{ }^{\circ} \mathrm{A},{ }^{\circ}$ and $^{\circ} \mathrm{T},{ }^{\circ}$ to ${ }^{\circ}$ study ${ }^{\circ}$ the ${ }^{\circ}$ fragmentation patterns in detail. These series were chosen because they are nonself-complementary, have repeating sequences (to simplify interpretation of fragmentation patterns), and possess the ability to introduce diversity via the central base.

\section{Experimental}

\section{ESI-Quadrupole Ion Trap Mass Spectrometer}

All ODNs were purchased from Sigma Genosys (The Woodlands, Texas) and used without further purification. A final concentration of $12.5 \mu \mathrm{M}$ each ODN in water with $20 \%$ methanol was directly infused into the mass spectrometer. Negative ion ESI-MS spectra were obtained with the Finnigan LCQ mass spectrometer (San Jose, CA). The spray voltage was $-4.0 \mathrm{kV}$, and capillary temperature was $175^{\circ} \mathrm{C}$. Collision induced dissociation ${ }^{\circ}(\mathrm{CID})^{\circ}$ was $^{\circ}$ performed ${ }^{\circ}{ }^{\circ}$ the $^{\circ}$ mass $^{\circ}$ analyzer by varying the resonance excitation amplitude (REA) with a default activation time of $30 \mathrm{~ms}$ and a $q$ value of 0.25 . The REA is defined as a percentage of $5 \mathrm{~V}_{p-p}$. REA values from 6 to $20 \%$ in increasing increments of $2 \%$ were applied to the parent ion to monitor the fragmentation under these low-energy collision conditions. Note that throughout the paper, $[\mathrm{M}-\mathrm{nH}]^{\mathrm{n}-}$ ions are labeled ${ }^{\circ}$ as $^{\circ /}[\mathrm{M}]^{\mathrm{n}-\prime \prime}{ }^{\circ}$ ions ${ }^{\circ}$ to $^{\circ}$ simplify ${ }^{\circ}$ notation. ${ }^{\circ}$ Therefore, an $[\mathrm{M}-2 \mathrm{H}]^{2-}$ ion is simply noted as an $[\mathrm{M}]^{2-}$ ion. The reason for this is that the ions formed via electrospray, when fragmented, cleave a nucleobase as the initial

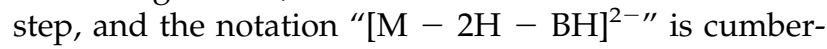
some $[8]$.

\section{Computational Methods}

Acidities of the phosphate moiety of the deoxy mononucleotides ${ }^{\circ}$ were $^{\circ}$ calculated $^{\circ}$ at $^{\circ}$ the ${ }^{\circ}$ AM1 $^{\circ}[19]^{\circ}$ and B3LYP $/ 3-21^{\circ}+{ }^{\circ} \mathrm{G}^{* \circ}[20]^{\circ}$ levels $^{\circ}$ using $^{\circ} \mathrm{Gaussian}^{\circ} 98^{\circ}$ and Gaussian 03; reported values are deprotonation enthalpies ${ }^{\circ}{ }^{\circ}{ }^{\circ}{ }^{\circ} \mathrm{K}^{\circ}$ [21]. Proton $^{\circ}$ affinities ${ }^{\circ}(\mathrm{PA})^{\circ}$ of ${ }^{\circ}$ the ${ }^{\circ}$ nucleobase moiety of the charged and uncharged deoxy mononucleotides ${ }^{\circ}$ were $^{\circ}$ calculated $^{\circ}$ at $^{\circ} \mathrm{AM}^{\circ}{ }^{\circ}$ using $^{\circ} \mathrm{Gaussian}^{\circ} 98$ and Gaussian 03; reported values are at $0 \mathrm{~K}$. To minimize the possibility of a strong gas-phase internal hydrogen ${ }^{\circ}$ bond ${ }^{\circ}$ forming ${ }^{\circ}$ from $^{\circ} a^{\circ}$ nearby ${ }^{\circ}$ heteroatom ${ }^{\circ}$ to either the terminal $-\mathrm{OH}$ or the phosphate $-\mathrm{OH}$ groups, a methoxy $\left(-\mathrm{OCH}_{3}\right)$ group was placed at each of $^{\circ}$ these $^{\circ}$ sites $^{\circ}\left(\right.$ Figure $\left.^{\circ} 2\right) .{ }^{\circ}$ For $^{\circ}$ the $^{\circ} \mathrm{AM} 1^{\circ}$ calculations, $^{\circ}$ an experimental $\Delta \mathrm{H}_{\mathrm{f}}^{\circ}\left(\mathrm{H}^{+}\right)$of $367.2 \mathrm{kcal} \mathrm{mol}^{-1}$ was used to 


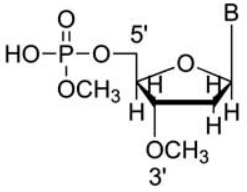

deoxynucleoside 5'-monophosphate (dpB)

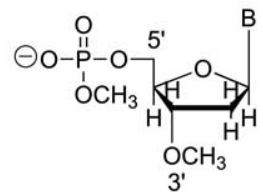

deoxynucleoside 5'-monophosphate anion ( $\left.\mathrm{dpB}^{-}\right)$

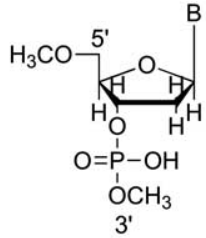

deoxynucleoside 3'-monophosphate (dBp)

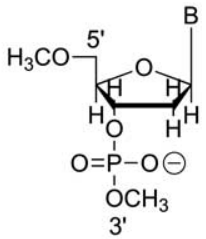

deoxynucleoside $3^{\prime}$-monophosphate anion $\left(\mathrm{dBp}^{-}\right)$

Figure 2. Structures of calculated methylated mononucleotides; $\mathrm{B}=$ base $=\mathrm{A}$ (adenine), $\mathrm{G}$ (guanine), C (cytosine), T (thymine).

calculate the acidity and proton affinity at each site since AM1 gives a very poor estimate of the heat of formation ${ }^{\circ}$ of $^{\circ} \mathrm{H}^{+}$[22]. Electrostatic ${ }^{\circ}$ potential maps ${ }^{\circ}$ of the deprotonated nucleobases were calculated at B3LYP/ $6-31^{\circ}+{ }^{\circ} \mathrm{G}^{* \circ}$ using ${ }^{\circ} \mathrm{Gaussian}^{\circ} 03^{\circ}[21]^{\circ} .^{\circ}$ Figures ${ }^{\circ}$ were ${ }^{\circ}$ generated with GaussView 3.0 (isodensity setting 0.0004, electrostatic potential range \pm 0.192 a.u.).

\section{Results and Discussion}

\section{Full-Scan Mass Spectra}

Charge state distribution: overall trends. The first characteristic that we explored for the ODN 9-mers $5^{\prime}$-GGTTXTTGG- $3^{\prime}{ }^{\circ}$ and ${ }^{\circ} 5^{\prime}-$ CCAAYAACC $-3^{\prime}{ }^{\circ}\left(X^{\circ}\right.$ and ${ }^{\circ} Y^{\circ}={ }^{\circ} \mathrm{A},{ }^{\circ} \mathrm{G}$,

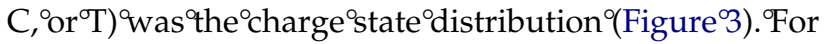
the $\mathrm{X}$-series, the -6 charge state comprises, on average, $4.3 \%$ of the total ion abundance. The -5 charge state is on average much more prevalent than the -6 charge state, with an average abundance of $27.5 \%$. The -4 charge state is present at $37.5 \%$, the -3 at $24.9 \%$, and the -2 at $5.8 \%$. For the Y-series, the corresponding average abundances are $3.3 \%(-6), 19.3 \%(-5), 46.9 \%(-4)$, $24.0 \%(-3)$, and $8.1 \%(-2)$. The distribution of charge states is similar for both the $\mathrm{X}$ - and $\mathrm{Y}$-series in a general sense, in that about $90 \%$ of the total ion abundance for each single strand resides at the $-5,-4$, and -3 charge states. The most abundant ions for both the $X$ - and the $\mathrm{Y}$-series are at the -4 charge state. In the $\mathrm{X}$-series, the -6 and -5 ions constitute 4.3 and $27.5 \%$ of the total abundance, while in the Y-series, these two states are present at only 3.3 and $19.3 \%$. Therefore, apparently the $\mathrm{X}$-series favors, on average, higher charge states than does the Y-series.

Charge distribution. Why does the X-series prefer higher charge states? The $\mathrm{X}$-series is rich in guanine and thymine, and prefers higher charge states than does the cytosine- and adenine-rich Y-series. Previous experi-
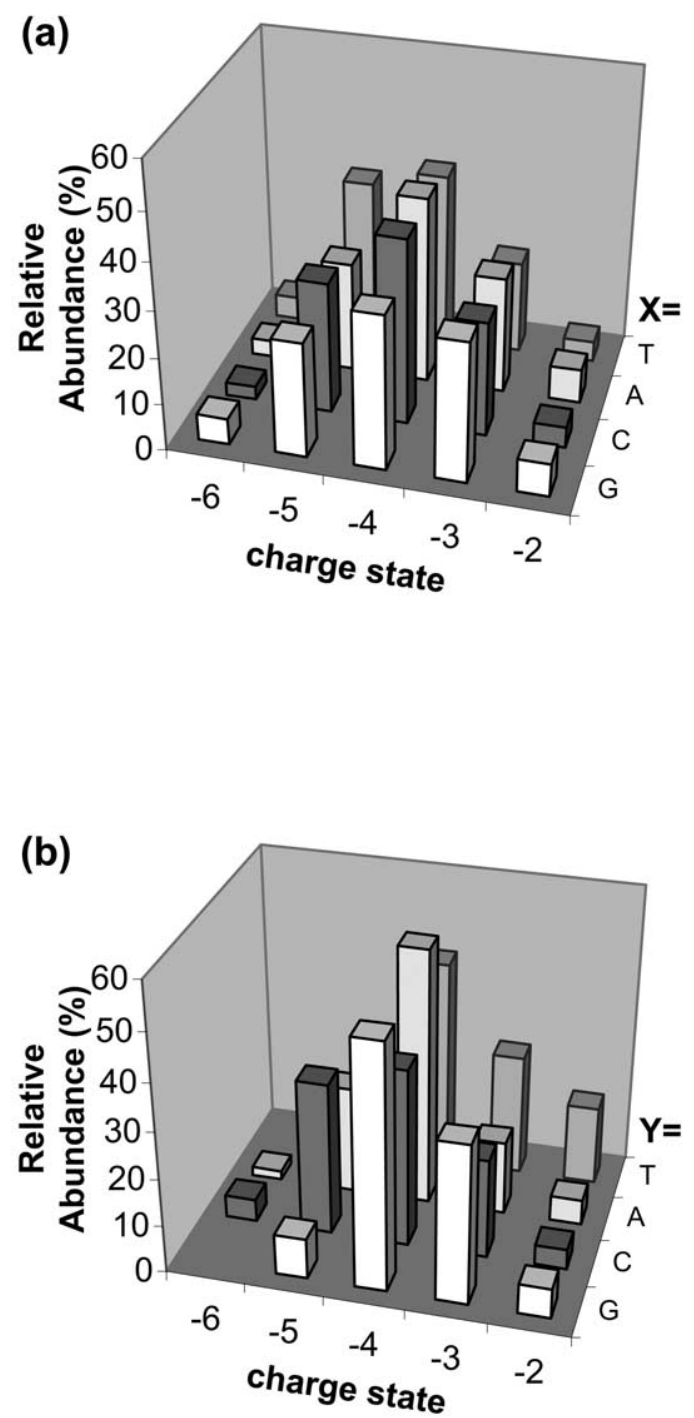

Figure 3. Charge distribution of 9-mer oligonucleotides in full scan mode; (a) 5'- d(GGTTXTTGG) $-3^{\prime}$ and (b) 5'- d(CCAAYAACC) $-3^{\prime}$, where $X$ and $Y$ are $G, C, A$, and $T$. 
Table 1. Acidity of the phosphate group of the eight mononucleotides calculated at AM1 and at B3LYP/3-21 + G* at 0 K. The most acidic site is shown in bold for each mononucleotide. Nomenclature is defined in Figure 2

\begin{tabular}{|c|c|c|c|c|c|}
\hline \multirow[b]{2}{*}{$5^{\prime}-$} & \multicolumn{2}{|c|}{ Acidity (kcal mol $\left.{ }^{-1}\right)$} & \multirow[b]{2}{*}{$3^{\prime}-$} & \multicolumn{2}{|c|}{ Acidity (kcal mol ${ }^{-1}$ ) } \\
\hline & AM1 & B3LYP/3-21+G* & & AM1 & B3LYP/3-21+G* \\
\hline $\mathrm{dpT}$ & 321.7 & 303.3 & $\mathrm{dTp}$ & 324.0 & 307.3 \\
\hline $\mathrm{dpC}$ & 323.8 & 308.3 & $\mathrm{dAp}$ & 325.9 & 310.0 \\
\hline $\mathrm{dpA}$ & 325.5 & 309.7 & $\mathrm{dCp}$ & 326.6 & 310.2 \\
\hline $\mathrm{dpG}$ & 327.3 & 312.6 & $\mathrm{dGp}$ & 325.3 & 310.6 \\
\hline
\end{tabular}

mental results are consistent with this observation. Williams and coworkers examined the dissociation of negatively-charged proton-bound dimers [dAMP. $\mathrm{dTMP}^{-}$and $[\mathrm{dGMP} \cdot \mathrm{dCMP}]^{-}$(where "XMP" represents the 5 '-deoxyribose monophosphate ${ }^{\circ}$ derivative ${ }^{\circ}$ of $^{\circ}$ nucleobase $\left.^{\circ} \mathrm{X}\right)^{\circ}$ and $^{\circ}$ noted $^{\circ}$ that $^{\circ}$ dissociation $^{\circ}$ of ${ }^{\circ}$ these dimers preferentially leads to the charge residing on $\mathrm{TMP}^{\circ}$ and ${ }^{\circ} \mathrm{GMP},{ }^{\circ}$ respectively, ${ }^{\circ}$ not $^{\circ}$ on $^{\circ} \mathrm{AMP}^{\circ}$ or $^{\circ} \mathrm{CMP}$. These observations led the authors to conclude that TMP is more acidic than AMP and that GMP is more acidic ${ }^{\circ} \operatorname{than}^{\circ} \mathrm{CMP}^{\circ}[23] .{ }^{\circ}$ In $^{\circ}$ the ${ }^{\circ}$ dissociation ${ }^{\circ}$ of $^{\circ} \mathrm{a}^{\circ}$ series $^{\circ}$ of complementary DNA duplexes into single strands, Gabelica and DePauw also observed that negative charges remain ${ }^{\circ}$ preferentially ${ }^{\circ}$ on $^{\circ}$ the ${ }^{\circ}$ strands $^{\circ}$ that ${ }^{\circ}$ bear ${ }^{\circ} \mathrm{G}^{\circ}$ rather than ${ }^{\circ} \mathrm{C},{ }^{\circ}$ and $^{\circ} \mathrm{T}^{\circ}$ rather $^{\circ}$ than $^{\circ} \mathrm{A}^{\circ}[24] .{ }^{\circ} \mathrm{To}^{\circ}$ investigate ${ }^{\circ}$ the possibility that the nucleobase may play a role in stabilizing or destabilizing the backbone charges through some type of long-range interaction, we calculated the acidities of the phosphate groups on the methylated ${ }^{\circ}$ deoxynucleoside ${ }^{\circ} 5^{\prime}-{ }^{\circ}$ and $^{\circ} 3^{\prime}$-monophosphates $^{\circ}\left(\right.$ Figure $^{\circ} 2,{ }^{\circ}$ Table $\left.^{\circ} 1\right){ }^{\circ}$ To $^{\circ}$ our $^{\circ}$ knowledge, $^{\circ}$ these values have not heretofore been computed. The acidity is defined as the energy that is required to deprotonate the ${ }^{\circ}$ neutral ${ }^{\circ}$ phosphoric ${ }^{\circ}$ acid $^{\circ}$ to $^{\circ}$ form ${ }^{\circ}$ the ${ }^{\circ}$ anionic ${ }^{\circ}$ phosphate. For both the deoxynucleoside-5' - and 3'-monophosphates, thymidine monophosphate (dpT and dTp) has the highest acidity at the phosphate site; this holds true at both the AM1 and DFT levels. The overall trend, particularly clear at the higher DFT level, is that thymidine monophosphate is the most acidic and that the other three nucleotides are quite close in acidity. The high acidity of the phosphate group of the thymidine monophosphate should translate to the negatively charged phosphate being more stable for thymidine monophosphate than for the other monophosphates. Thus, our calculations imply that the identity of the nucleobase does have an effect on the stability of the nearest negatively charged phosphate, with thymine providing the greatest stability of the deprotonated phosphate. In solution, all the phosphates in DNA are "deprotonated", with counterions to balance the negative charges. When electrosprayed, certain phosphates get protonated, such that the DNA strand ultimately has some number of charges that is less than the total number of phosphates. Because thymine ribose monophosphates are stable anions, thymine-rich series tend to have higher charge states. Therefore, it is not surprising that the thymine-rich $\mathrm{X}$-series prefers higher ${ }^{\circ}$ charge $^{\circ}$ states $^{\circ}$ than does ${ }^{\circ}$ the ${ }^{\circ} Y$-series.

\section{Collision-Induced Dissociation}

Fragmentation and Charge State. We next conducted dissociation studies of the X- and Y-series ODNs under gentle collision conditions to examine the initial fragmentation patterns. Regardless of the charge state, the ODN ions start to fragment at a resonance excitation amplitude ${ }^{\circ}(\text { REA })^{\circ}$ of ${ }^{\circ} 6^{\circ}$ to ${ }^{\circ} 12 \%$. In ${ }^{\circ}$ Figure $^{\circ} 4,{ }^{\circ}$ we $^{\circ}$ show $^{\circ}$ the relative ${ }^{\circ}$ ion $^{\circ}$ intensities ${ }^{\circ}$ of the parent and product fragments ${ }^{\circ}$ for $^{\circ} \mathrm{CID}^{\circ}$ of ${ }^{\circ}$ the $\mathrm{e}^{\circ}-5^{\circ}$ (Figure $\left.{ }^{\circ} 4 \mathrm{a}\right)$, the $^{\circ}-4^{\circ}$ (Figure $\left.4 \mathrm{~b}\right)$, the ${ }^{\circ}-3^{\circ}$ (Figure $\left.4 \mathrm{c}\right)$, and ${ }^{\circ}$ the $\mathrm{O}^{\circ}-2^{\circ}$ (Figure $\left.4 \mathrm{~d}\right)^{\circ}$ charge $^{\circ}$ states of 5'-CCAACAACC-3'. Consistent with other studies, we find that the dominant initial fragmentation channel for the parent ions is base loss, either as ${ }^{\circ}$ the $e^{\circ}$ charged form ${ }^{\circ} \mathrm{B}^{-}$to $^{\circ}$ form ${ }^{\circ}\left(\mathrm{M}^{\circ}-{ }^{\circ} \mathrm{B}^{-}\right)$ions ${ }^{\circ}$ or $^{\circ}$ as $^{\circ}$ the ${ }^{\circ}$ neutral ${ }^{\circ}$ form $\mathrm{BH}$ to form (M-BH) ions. The specific bases lost for each charge $^{\circ}$ state $^{\circ}$ are $^{\circ}$ shown $^{\circ}$ as $^{\circ}$ inserts $^{\circ}$ in ${ }^{\circ}$ Figure $^{\circ} 4 .^{\circ}$ As $^{\circ}$ the REA is increased, the relative abundances of the sum of the $\left(\mathrm{M}-\mathrm{B}^{-}\right)$and $(\mathrm{M}-\mathrm{BH})$ ions (filled diamonds, Figure $\left.^{\circ} 4\right)^{\circ}$ initially ${ }^{\circ}$ increase $^{\circ}{ }^{\circ}$ and $^{\circ}$ then $^{\circ}$ decrease $^{\circ}$ as $^{\circ}(\mathrm{a}-\mathrm{B})$ and $\mathrm{w}$ ions form via cleavage of ${ }^{\circ}$ the ${ }^{\circ}$ phosphate ${ }^{\circ}$ backbone $^{\circ}$ (filled ${ }^{\circ}$ triangles, ${ }^{\circ}$ Figure $\left.^{\circ} 4\right)$. $^{\circ}$ The $(a-B)$ and $w$ ion abundances appear to reach a maximum around $16 \%$; at about $20 \%$, other fragments such as y and b ions ${ }^{\circ}$ start competing ${ }^{\circ}$ with $^{\circ}$ the $^{\circ}(\mathrm{a}-\mathrm{B})^{\circ}$ and $^{\circ} \mathrm{w}^{\circ}$ ion $^{\circ}$ fragments.

CID: overall trends (Table 2, Figure 4). The ${ }^{\circ}$ relative preference of nucleobase loss for the X-and Y-series at different ${ }^{\circ}$ charge $^{\circ}$ states $^{\circ}$ is $^{\circ}$ summarized $^{\circ}$ in ${ }^{\circ}$ Table $^{\circ} 2 .^{\circ}$ Base loss from the -6 ions is not included due to low intensities. At the -5 charge state, bases are lost exclusively as anions. At -4 , base loss is a mix of anionic and neutral forms. At the -3 and -2 charge states, only neutral loss is observed. While we only investigate 9-mers herein, we think it is useful to define a term that is independent of the length of the oligonucleotide, but still conveys the amount of negative charge that is carried. The ratio of the actual charge to the total possible charge for a given oligonucleotide gives us a "normalized" value that is independent of oligomer length and may be useful in future studies, especially for systems of varying length. For example, a 9-mer ion could hypothetically carry a total charge of -8 (one charge on each phosphate). For a -4 ion, the ratio of the actual ${ }^{\text {to }}$ the total $^{\circ}$ possible $^{\circ}$ charge $^{\circ}$ is $^{\circ} 4 / 8=50 \%$. We call 
(a) -5 charge state $(62.5 \%$ charge level)

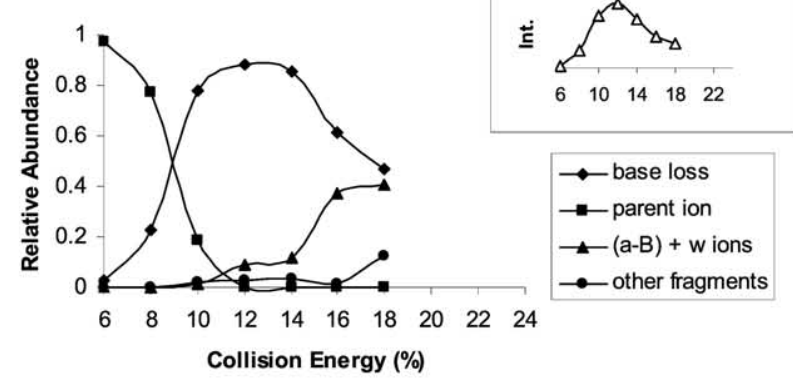

(b) -4 charge state $(50.0 \%$ charge level)

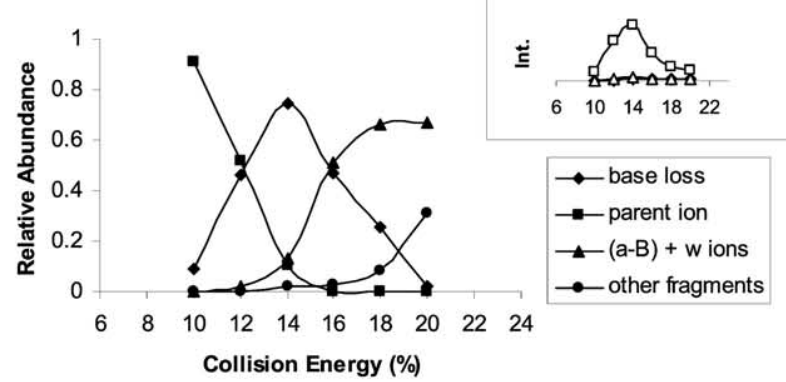

(c) -3 charge state $(37.5 \%$ charge level)

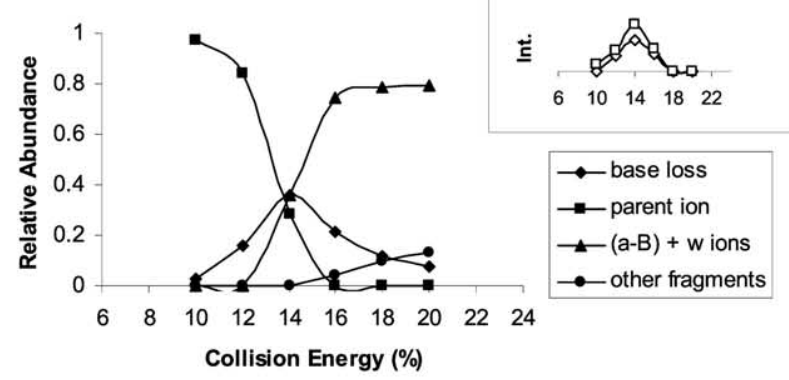

(d) -2 charge state $(25.0 \%$ charge level)

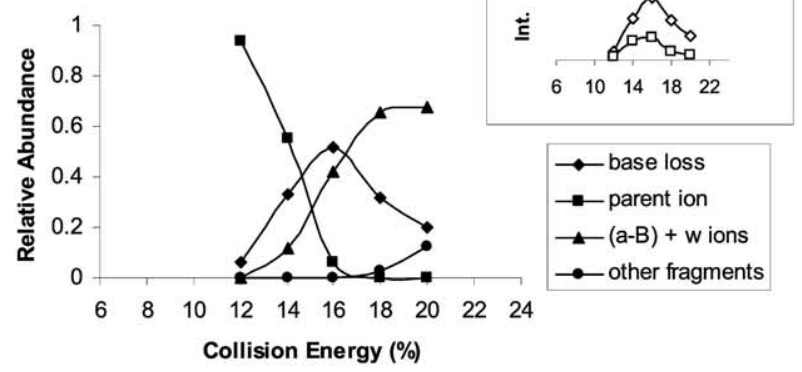

Figure 4. Parent ion and product ion relative intensities as a function of REA for 5'-CCAACAACC-3' at various charge states. For the main plots, filled squares indicate parent ions; filled diamonds, $\left[\mathrm{M}-\mathrm{B}^{-}\right]$and $[\mathrm{M}-\mathrm{BH}]$ ions; filled triangles, $(\mathrm{a}-\mathrm{B}) / \mathrm{w}$ ions; filled circles, other fragments. For the inserts, which show specific bases lost, open diamonds indicate $[\mathrm{M}-\mathrm{CH}]$ ions; open squares, $[\mathrm{M}-\mathrm{AH}]$ ions; and open triangles, $\left[\mathrm{M}-\mathrm{A}^{-}\right]$ions. this ${ }^{\circ}$ value ${ }^{\circ}$ the ${ }^{\circ \prime}$ charge ${ }^{\circ}$ level"..$[3]^{\circ}{ }^{\circ}$ Therefore, ${ }^{\circ}{ }^{\circ}{ }^{\circ}{ }^{\circ}$ charge level of $62.5 \%$ ( -5 charge state), all base loss is in the anionic form. At a charge level of $50 \%(-4)$, bases are lost as both anions and neutrals. At charge levels of $37.5 \%(-3)$ and $25 \%(-2)$, base loss is exclusively as a neutral. The "crossover" point is therefore somewhere around $^{\circ} 50 \%$; ${ }^{\circ}$ once $^{\circ}$ the ${ }^{\circ}$ charge $^{\circ}$ level $^{\circ}$ drops $^{\circ}$ below $^{\circ}$ that value, neutral base loss becomes favored. Future studies would involve ascertaining whether this $50 \%$ crossover holds true among different oligomers. Detailed analyses of the base loss preferences follow.

CHARGE LEVEL OF $62.5 \% . \quad \mathrm{B}^{-}{ }^{\circ} \operatorname{loss}^{\circ} \mathrm{is}^{\circ} \mathrm{dominant}^{\circ}$ (Table $2,{ }^{\circ}$ Figure $\left.{ }^{\circ} 4\right){ }^{\circ}{ }^{\circ}$ For $^{\circ}$ the ${ }^{\circ} \mathrm{Y}_{\text {-series }},{ }^{\circ} \mathrm{A}^{-}{ }^{\circ} \operatorname{loss}^{\circ}$ is ${ }^{\circ}$ prevalent ${ }^{\circ}$ and virtually no cytosine loss is observed. For the two $X$-series ${ }^{\circ}$-mers ${ }^{\circ}$ that ${ }^{\circ}$ have ${ }^{\circ}$ only ${ }^{\circ} G^{\circ}$ and ${ }^{\circ} T^{\circ}\left(X^{\circ}={ }^{\circ} G^{\circ}\right.$ and ${ }^{\circ} X^{\circ}=$ $\mathrm{T})$, both $\mathrm{G}^{-}$and $\mathrm{T}^{-}$are lost. For $\mathrm{X}=\mathrm{A}$ (5'-GGTTATTGG-3'), $\mathrm{A}^{-}$loss dominates, despite the fact that there is only one adenine present in the sequence. For $\mathrm{X}=\mathrm{C}$, $\mathrm{G}^{-}$, and $\mathrm{T}^{-}$loss is comparable, with a small amount of $\mathrm{C}^{-}$cleavage. The overall trend for base loss at charge level $62.5 \%$ appears to be $\mathrm{A}^{-} \gg \mathrm{G}^{-} \approx \mathrm{T}^{-}>\mathrm{C}^{-}$.

CHARGE LEVEL OF $\mathbf{5 0 . 0 \%}$. Base loss at this level is a mix $^{\circ}$ of $^{\circ}$ anionic ${ }^{\circ}$ and ${ }^{\circ}$ neutral ${ }^{\circ}{ }^{\circ}$ leavage ${ }^{\circ}$ (Table 2 , ${ }^{\circ}$ Figure $\left.^{\circ} 4\right)$. While ${ }^{\circ}$ there ${ }^{\circ}$ are $^{\circ}{ }^{\circ}{ }^{\circ}$ obvious ${ }^{\circ}$ trends ${ }^{\circ}$ for ${ }^{\circ}$ the ${ }^{\circ} X$-series, ${ }^{\circ}$ the $\mathrm{Y}$-series continues to favor the loss of adenine, both as $\mathrm{AH}$ and as $\mathrm{A}^{-}$, with $\mathrm{AH}$ loss being preferred over $\mathrm{A}^{-}$ loss.

CHARGE LEVELS OF $\mathbf{3 7 . 5}$ AND $\mathbf{2 5 . 0 \%}$. At these lower charge $\mathrm{O}^{\circ}$ levels, ${ }^{\circ}$ neutral ${ }^{\circ} \operatorname{loss}^{\circ}$ is $^{\circ}$ exclusive $^{\circ}\left(\right.$ Table $^{\circ} 2,{ }^{\circ}$ Figure 4). ${ }^{\circ}$ For ${ }^{\circ}$ the ${ }^{\circ} \mathrm{X}$-series, ${ }^{\circ} \mathrm{GH}^{\circ} \operatorname{loss}^{\circ}$ is ${ }^{\circ}$ favored, ${ }^{\circ}$ with ${ }^{\circ}$ some $^{\circ} \mathrm{AH}$ loss being observed when $\mathrm{X}=\mathrm{A}$. $\mathrm{TH}$ loss is not observed. For the Y-series, the base loss preference is dependent on the charge level. While $\mathrm{AH}$ loss is preferred over $\mathrm{CH}$ loss for charge level $37.5 \%$, the opposite is true for charge level $25.0 \%$. As with the X-series, there is no observable $\mathrm{TH}$ loss.

FURTHER INSIGHT INTO OVERALL TRENDS. The most intriguing trends from the charge level versus CID data are at the $37.5 \%$ and $25.0 \%$ charge levels: (1) why is $\mathrm{AH}$ loss preferred over $\mathrm{CH}$ loss at $37.5 \%$, but $\mathrm{CH}$ loss is preferred over $\mathrm{AH}$ loss at $25.0 \%$ for the Y-series; (2) what are the trends for GH loss? We know TH loss is rare, but the $\mathrm{X}$ and $\mathrm{Y}$-series do not allow us to address $\mathrm{GH}$ loss compared to $\mathrm{AH}$ and $\mathrm{CH}$ loss. To answer these questions, we chose two more sets of 9-mer noncomplementary ${ }^{\circ} \mathrm{ODNs}^{\circ}\left(\mathrm{Table}^{\circ} 3\right) .{ }^{\circ} \mathrm{The}^{\circ} \mathrm{two}^{\circ}$ oligonucleotides ${ }^{\circ}$ in Set I are designed to directly compare $\mathrm{AH}$ and $\mathrm{CH}$ loss. Both strands are comprised of four cytosine bases, four adenine bases, and a central thymine base, with the difference being in the two terminal bases on each end (CC versus AA; note that the first ODN in Set $\mathrm{I}$ is equivalent to the $\mathrm{Y}$-series $\mathrm{ODN}$ where $\mathrm{Y}=\mathrm{T}$ ). In these sequences, as in all our sequences, we try to have the same number of each base we expect to cleave. That is, we have the same number of cytosines as we do 
Table 2. Initial nucleobase loss preferences for the X- and Y-series ODNs. Charge level is in parentheses

\begin{tabular}{|c|c|c|c|c|}
\hline $\mathrm{X}=\mathrm{G}, \mathrm{C}, \mathrm{A}$, and $\mathrm{T}$ & $-5(62.5 \%)$ & $-4(50.0 \%)$ & $-3(37.5 \%)$ & $-2(25.0 \%)$ \\
\hline $\begin{array}{l}\text { 5'-GGTTGTTGG-3' } \\
\text { 5'-GGTTCTTGG-3' }^{\prime} \text { 5'-GGTTATTGG-3' } \\
5^{\prime} \text {-GGTTTTTGG-3' }\end{array}$ & $\begin{array}{l}\mathrm{G}^{-}>\mathrm{T}^{-} \\
\mathrm{G}^{-} \approx \mathrm{T}^{-}>\mathrm{C}^{-} \\
\mathrm{A}^{-} \\
\mathrm{T}^{-}>\mathrm{G}^{-}\end{array}$ & $\begin{array}{l}\mathrm{GH}>\mathrm{G}^{-} \\
\mathrm{CH} \geq \mathrm{GH} \geq \mathrm{G}^{-} \\
\mathrm{AH}>\mathrm{GH} \\
\mathrm{GH}>\mathrm{G}^{-}\end{array}$ & $\begin{array}{l}\mathrm{GH} \\
\mathrm{GH} \\
\mathrm{GH}>\mathrm{AH} \\
\mathrm{GH}\end{array}$ & $\begin{array}{l}\mathrm{GH} \\
\mathrm{GH} \\
\mathrm{GH}>\mathrm{AH} \\
\mathrm{GH}\end{array}$ \\
\hline $\mathrm{Y}=\mathrm{G}, \mathrm{C}, \mathrm{A}$ and $\mathrm{T}$ & $-5(62.5 \%)$ & $-4(50.0 \%)$ & $-3(37.5 \%)$ & $-2(25.0 \%)$ \\
\hline $\begin{array}{l}5^{\prime}-\text { CCAAGAACC-3' } \\
5^{\prime}-\text { CCAACAACC-3' } \\
5^{\prime}-\text { CCAAAAACC-3' } \\
5^{\prime} \text {-CCAATAACC- } 3^{\prime}\end{array}$ & $\begin{array}{l}A^{-} \\
A^{-} \\
A^{-} \\
A^{-}\end{array}$ & $\begin{array}{l}\mathrm{AH}>\mathrm{A}^{-} \\
\mathrm{AH}>\mathrm{A}^{-} \\
\mathrm{AH} \\
\mathrm{AH}\end{array}$ & $\begin{array}{l}\mathrm{AH}>\mathrm{CH}>\mathrm{GH} \\
\mathrm{AH}>\mathrm{CH} \\
\mathrm{AH}>\mathrm{CH} \\
\mathrm{AH}>\mathrm{CH}\end{array}$ & $\begin{array}{l}\mathrm{CH}>\mathrm{AH}>\mathrm{GH} \\
\mathrm{CH}>\mathrm{AH} \\
\mathrm{CH}>\mathrm{AH} \\
\mathrm{CH}>\mathrm{AH}\end{array}$ \\
\hline
\end{tabular}

adenines, so as not to favor loss of one over the other by having more of one present in a given sequence. The two sequences in Set II are for the comparison of AH and $\mathrm{GH}$ loss. Both have a $\mathrm{T}$ as the central base, with the terminal bases being GG or AA, for a total of four guanines and four adenines in both sequences. At a charge level of $37.5 \%$, the neutral base loss trend is $\mathrm{AH}$ $>\mathrm{CH}$ and $\mathrm{AH} \geq \mathrm{GH}$. However, at $25.0 \%$, terminal bases are cleaved preferentially over interior bases, regardless of identity. Thus for Set I, the sequence 5'-CCAATAACC-3' shows a $\mathrm{CH}$ loss preference, while 5'-AACCTCCAA-3' shows an AH loss preference. Set II follows the same trend of favoring terminal base cleavage at charge level $25 \%$.

A direct comparison of the relative reactivity of $\mathrm{C}$ and $G$ was complicated by the fact that $C / G$-rich sequences such as GGCCTCCGG tend to form dimers and interpretation of the CID spectrum is not straightforward, since a dimer with -4 charge is indistinguishable from a single strand with -2 charge.

\section{Anionic base loss}

ACIDITY ARGUMENTS. It has been proposed that the loss of a nucleobase in its deprotonated form, $\mathrm{B}^{-}$, should be $^{\circ}$ related ${ }^{\circ}$ to ${ }^{\circ}$ the ${ }^{\circ}$ acidity ${ }^{\circ}$ of ${ }^{\circ} \mathrm{BH}{ }^{\circ}[15]$. Presumably, the higher the acidity of $\mathrm{BH}$, the better a leaving group $\mathrm{B}^{-}$will be, leading to preferential $\mathrm{B}^{-}$loss during fragmentation. In this study, $\mathrm{B}^{-}$loss follows the trend: $\mathrm{A}^{-} \gg \mathrm{G}^{-} \approx \mathrm{T}^{-}>\mathrm{C}^{-}$, where $\mathrm{A}^{-}$loss is most prevalent. Earlier studies by McLuckey and Beauchamp on different systems showed a preference of $\mathrm{A}^{-}>\mathrm{T}^{-}>\mathrm{G}^{-}, \mathrm{C}^{-}$, which is roughly in agreement with our results in that $\mathrm{A}^{-}$is most easily cleaved, and $\mathrm{C}^{-}$is least easily cleaved $\left[1,{ }^{\circ} 15,{ }^{\circ} 16\right] .{ }^{\circ}$ Calculations ${ }^{\circ}$ of ${ }^{\circ}$ the ${ }^{\circ}$ acidity ${ }^{\circ}{ }^{\circ}{ }^{\circ} \mathrm{BH}^{\circ}{ }^{\circ} t^{\circ} \mathrm{B} 3 \mathrm{LYP} /$

Table 3. Initial nucleobase loss preferences for three sets of 9-mer single stranded oligonucleotides. Charge level is in parentheses

\begin{tabular}{cccc}
\hline & Sequence & $-3(37.5 \%)$ & $-2(25 \%)$ \\
\hline \hline Set I & $5^{\prime}$-CCAATAACC-3' & $\mathrm{AH}>\mathrm{CH}$ & $\mathrm{CH}>\mathrm{AH}$ \\
& $5^{\prime}$-AACCTCCAA-3' & $\mathrm{AH}>\mathrm{CH}$ & $\mathrm{AH}>\mathrm{CH}$ \\
Set II & $5^{\prime}$-GGAATAAGG-3' & $\mathrm{AH}>\mathrm{GH}$ & $\mathrm{GH}>\mathrm{AH}$ \\
& $5^{\prime}$-AAGGTGGAA-3' & $\mathrm{AH} \geq \mathrm{GH}$ & $\mathrm{AH}>\mathrm{GH}$ \\
\hline
\end{tabular}

6-31 $+\mathrm{G}^{* *}$ by Zeegers-Huyskens and coworkers indicate that $\mathrm{TH}$ is the most acidic, with an overall (decreasing) ${ }^{\circ}$ acidity ${ }^{\circ}$ order ${ }^{\circ}$ of: ${ }^{\circ} \mathrm{TH}^{\circ}>{ }^{\circ} \mathrm{GH}^{\circ} \approx{ }^{\circ} \mathrm{AH}^{\circ}>{ }^{\circ} \mathrm{CH}[25]$. These computational acidity results are not consistent with the observed $\mathrm{B}^{-}$loss; one would expect the most acidic $\mathrm{TH}$ to correlate to a highly stable $\mathrm{T}^{-}$, and hence, a strong preference for $\mathrm{T}^{-}$loss during fragmentation. Instead, $\mathrm{A}^{-}$is preferentially cleaved. The only consistency between the acidity calculations and the experimentally observed anionic base loss trends is with cytosine: $\mathrm{CH}$ is least acidic, and $\mathrm{C}^{-}$appears to be cleaved least frequently.

The lack of correlation between acidity and cleavability may arise from the acidity being a thermodynamic property, while the ease of base loss is dependent on the barrier associated with bond cleavage, which is related to kinetics. Acidity can therefore give a "feeling" for how ${ }^{\circ}$ easily ${ }^{\circ}$ an $^{\circ}$ anionic ${ }^{\circ}$ base $^{\circ}$ might $^{\circ}$ cleave, $^{\text {but }}{ }^{\circ}$ is ${ }^{\circ}$ not $^{\circ}$ the only factor. Furthermore, the calculated acidity difference between $\mathrm{TH}$ and $\mathrm{GH}$ is only $2.3 \mathrm{kcal} \mathrm{mol}^{-1}$; GH and $\mathrm{AH}$ differ by only $0.3 \mathrm{kcal} \mathrm{mol}^{-1} . \mathrm{CH}$, in contrast, is calculated to be less acidic than $\mathrm{TH}$ by nearly $10 \mathrm{kcal}$ $\mathrm{mol}^{-1^{\circ}}[25]$. Perhaps the acidities ${ }^{\circ}{ }^{\circ}{ }^{\circ} \mathrm{TH},{ }^{\circ} \mathrm{AH}$, and ${ }^{\circ} \mathrm{GH}^{\circ}$ are too close to translate to differences in anionic base loss.

CHARGE DELOCALIZATION ARGUMENTS. Another interesting feature is the charge delocalization in the $\mathrm{B}^{-}$ formed via cleavage from the ODN. Greater delocalization in an anion should translate to greater stability, and therefore, a preference for cleavage. One way to assess delocalization in an anion is to "count" the number of possible $^{\circ}$ resonance $^{\circ}$ structures $^{\circ}\left(\right.$ Figure $\left.^{\circ} 5\right) .{ }^{\circ} \mathrm{A}^{-{ }^{\circ}}$ has ${ }^{\circ}$ four possible resonance structures, while $\mathrm{G}^{-}$and $\mathrm{T}^{-}$have only three possible resonance structures, and $\mathrm{C}^{-}$has only two possible'resonance structures. More'resonance structures would roughly imply greater stability and may help explain why $\mathrm{A}^{-}$loss is most prevalent (most resonance structures and most charge delocalization) while $\mathrm{C}^{-}$loss is least favorable (fewest resonance structures and least charge delocalization). To lend further insight into this argument, we calculated the electrostatic ${ }^{\circ}$ potentials ${ }^{\circ}$ for $^{\circ}$ the ${ }^{\circ}$ deprotonated ${ }^{\circ}$ uncleobases ${ }^{\circ}$ (Figure ${ }^{\circ 5)} .^{\circ}$ The $^{\circ}$ color $^{\circ}$ at $^{\circ}$ each $^{\circ}$ point $^{\circ}$ on $^{\circ}$ these ${ }^{\circ}$ surfaces ${ }^{\circ}$ reflects the interaction energy between the molecule and a 


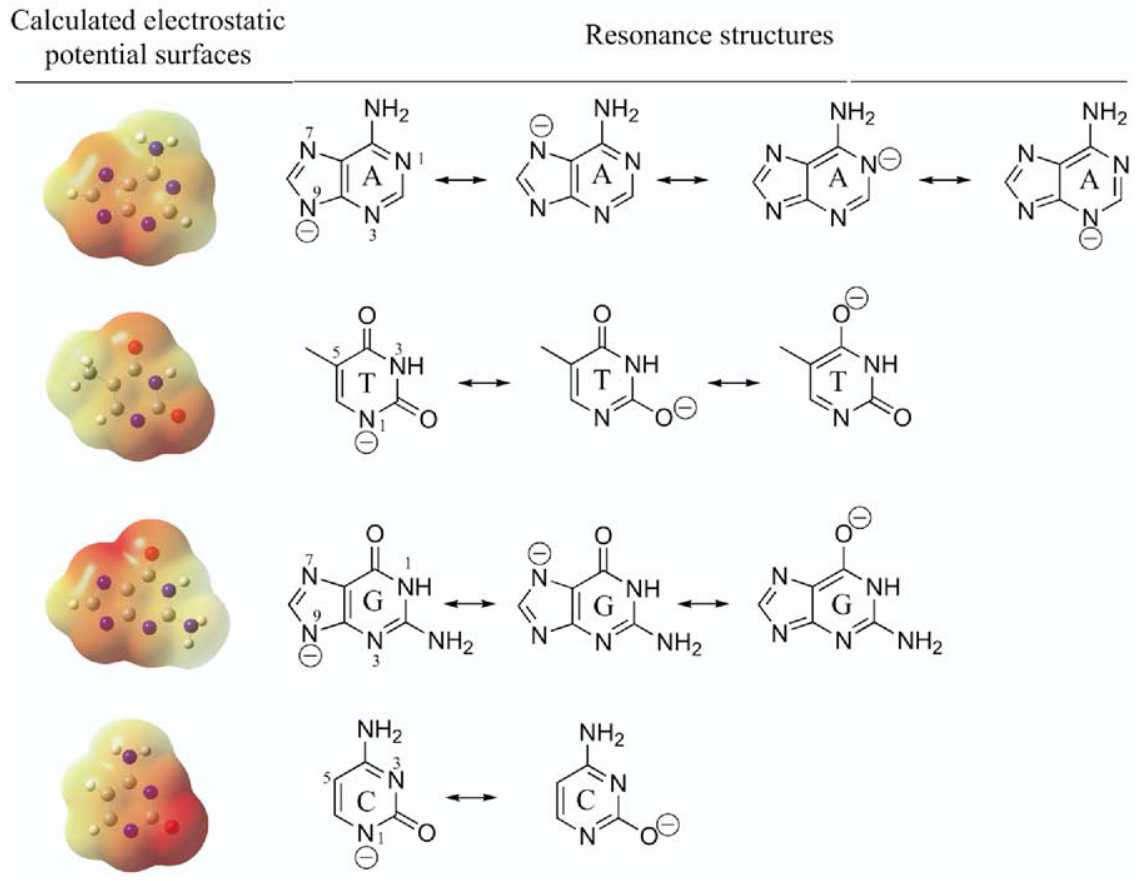

Figure 5. Black and white stick drawings show the resonance structures for $\mathrm{A}^{-}, \mathrm{T}^{-}, \mathrm{G}^{-}$, and $\mathrm{C}^{-}$ions formed via cleavage from an ODN. The color renderings show calculated electrostatic potential surfaces for each anion. Red indicates negative potential while blue indicates positive potential.

positive test charge at that point. A red color indicates attractive potential while blue represents repulsive potential. These anions have an attractive potential to a positive test charge, so the overall surface is quite red. The areas of pale red indicate a less "negative" region; yellow/green indicates a more neutral or "positive" region, depending on how bluish the color. For $\mathrm{A}^{-}$, the electrostatic potential is as we would expect for a delocalized anion; there are areas of pale red around N1, N3, N5, and N7, but no one site is particularly bright red, indicating that the negative charge is "spread" throughout the molecule. In contrast, the $\mathrm{C}^{-}$ ion shows a very bright red color in the $\mathrm{C} 2=\mathrm{O}$ region, indicating that most of the negative charge resides in that location; that is, the charge is not very delocalized. The $\mathrm{T}^{-}$and $\mathrm{G}^{-}$electrostatic potentials appear "in between" those of $\mathrm{A}^{-}$and $\mathrm{C}^{-}$: not as delocalized as $\mathrm{A}^{-}$, but more delocalized than $\mathrm{C}^{-}$. Thus, the electrostatic potentials indicate, as do the resonance structures, that $\mathrm{A}^{-}$ion is most delocalized, most stable, and most likely to be cleaved, while the $\mathrm{C}^{-}$ion is least delocalized, and therefore least stable and least likely to be cleaved, with $\mathrm{T}^{-}$and $\mathrm{G}^{-}$being in between; these computational results are consistent with the anionic base loss trend $\mathrm{A}^{-} \gg \mathrm{G}^{-} \approx \mathrm{T}^{-}>\mathrm{C}^{-}$.

We should also note that the calculated acidities do not track with the stability of the anions as expressed by resonance structures; that is, the anion stability by charge delocalization arguments is $\mathrm{A}^{-}>\mathrm{G}^{-} \approx \mathrm{T}^{-}>\mathrm{C}^{-}$ while the acidity trend is, from most to least acidic, $\mathrm{TH}$ $>\mathrm{GH} \approx \mathrm{AH}>\mathrm{CH}$. One might expect $\mathrm{TH}$, which is most acidic, to translate to $\mathrm{T}^{-}$being most stable, but the issue here is the reference state. Although TH is more acidic than $\mathrm{GH}$, comparison of $\mathrm{T}^{-}$to $\mathrm{G}^{-}$may be complicated by the fact that $\mathrm{TH}$ and $\mathrm{GH}$ are different molecules.

Neutral base loss. For the $\mathrm{X}$-series, since $\mathrm{TH}$ is rarely lost, we observe mostly GH loss. The Y-series and the additional ${ }^{\circ} \mathrm{Sets}^{\circ} \mathrm{I}^{\circ}$ and ${ }^{\circ} \mathrm{II}^{\circ}\left(\text { Table }^{\circ} 2,{ }^{\circ} \text { Table }^{\circ} 3\right)^{\circ}$ are ${ }^{\circ}$ more intriguing. At a charge level of $37.5 \%$ ( -3 charge state), $\mathrm{BH}$ is lost with the preference order of $\mathrm{AH}>\mathrm{CH}$ and $\mathrm{AH}^{\circ} \geq{ }^{\circ} \mathrm{GH} .{ }^{\circ} \mathrm{At}^{\circ} \mathrm{a}^{\circ} \mathrm{charge}^{\circ}$ level ${ }^{\circ}$ of $25.0 \%{ }^{\circ}\left(-2^{\circ}\right.$ charge $^{\circ}$ state $)$, the terminal bases are preferentially lost over internal bases. Consequently, our goals are: (1) to rationalize the preference differences that we see at charge level 37.5 versus $25.0 \%$; (2) to examine how the charge affects fragmentation patterns.

PROTON AFFINITY ARGUMENTS. Just as acidity has been proposed to correlate with $\mathrm{B}^{-}$loss, proton affinity (PA) has been proposed to correlate with neutral base

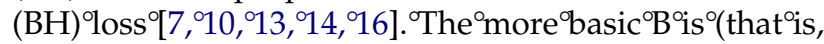
the higher ${ }^{\circ}{ }^{\circ}{ }^{\circ}$ proton ${ }^{\circ}$ affinity), ${ }^{\circ}$ the ${ }^{\circ}$ more likely ${ }^{\circ}{ }^{\circ}{ }^{\circ}{ }^{\circ}{ }^{\circ}$ to $\mathrm{be}$ protonated, which should in turn promote $\mathrm{BH}$ loss. Examination of the theoretical PA values for the nucleobases and their respective nucleosides in the literature yields an overall trend of $C \approx G>A \gg T$, where $T$ is least ${ }^{\circ}$ basic $^{\circ}[25-28]^{\circ} .^{\circ}$ sing $^{\circ}$ the ${ }^{\circ}$ kinetic $^{\circ}$ method $^{\circ}$ with $^{\circ}$ fast atom bombardment mass spectrometry, Sindona and coworkers determined the PAs for the free nucleobases (G 227.4 > C $225.9>$ A $224.2 \gg$ T $209.0 \mathrm{kcal} \mathrm{mol}^{-1}$ ) and the corresponding deoxyribose nucleosides (dG 234.4 > $\mathrm{dA}^{\circ} 233.6^{\circ} \approx^{\circ} \mathrm{dC}^{\circ} 233.2^{\circ} \gg{ }^{\circ} \mathrm{dT}^{\circ} 224.9^{\circ} \mathrm{kcal}^{\circ} \mathrm{mol}^{-1^{\circ}}$ [29]. 
Table 4. Proton affinities of the nucleobase portion of $5^{\prime}$ - and $3^{\prime}$-neutral ${ }^{\circ}$ and $^{\circ}$ anionic $^{\circ}$ mononucleotides $^{\circ}$ calculated $^{\circ}$ at ${ }^{\circ}$ the ${ }^{\circ}$ AMI level. ${ }^{\circ}$ Nomenclature ${ }^{\circ}$ is ${ }^{\circ}$ defined ${ }^{\circ}$ in $^{\circ}$ Figure $^{\circ} 2$

\begin{tabular}{cccccc}
\hline & & \multicolumn{4}{c}{ AM1 calculation (kcal mol ${ }^{-1}$ ) } \\
\cline { 3 - 6 } & & $\mathrm{dBp}^{-}$ & $\mathrm{dpB}^{-}$ & $\mathrm{dBp}$ & $\mathrm{dpB}$ \\
\hline \hline $\mathrm{A}$ & $\mathrm{N} 1$ & 269.5 & 278.1 & 228.0 & 226.7 \\
& $\mathrm{~N} 3$ & 274.2 & 301.1 & 229.3 & 233.4 \\
$\mathrm{G}$ & $\mathrm{N} 7$ & 281.2 & 300.3 & 234.9 & 233.2 \\
$\mathrm{C}$ & O2 & 278.9 & 289.2 & 231.0 & 229.9 \\
& $\mathrm{~N} 3$ & 282.0 & 293.6 & 235.3 & 233.8 \\
$\mathrm{~T}$ & O4 & 262.1 & 274.6 & 215.3 & 212.8 \\
\hline
\end{tabular}

Green-Church and Limbach reported PAs for the nucleobase ${ }^{\circ}$ component ${ }^{\circ}$ of the neutral (deoxy)nucleoside 5'- and 3'-monophosphates (dpA 237.4 > dpG $237.0>$ $\mathrm{dpC} 236.0 \gg \mathrm{dpT} 224.1$, and dAp $236.4>\mathrm{dGp} 235.5>$ $\mathrm{dCp} 234.8 \gg \mathrm{dTp} 225.6 \mathrm{kcal} \mathrm{mol}^{-1}$ ) using the kinetic method $^{\circ}[30] .{ }^{\circ}$ Roughly $^{\circ}$ speaking, ${ }^{\circ}$ the ${ }^{\circ}$ theoretical ${ }^{\circ}$ and experimental PA values of thymine are much lower than those of the other nucleobases, in agreement with the fact that the loss of thymine is rarely observed in ODN fragmentation under gentle collision conditions $\left[5,9,{ }^{\circ} 13,{ }^{\circ} 17\right] .{ }^{\circ}$ However, ${ }^{\circ}$ the ${ }^{\circ}$ closeness ${ }^{\circ}$ of ${ }^{\circ}$ the ${ }^{\circ} \mathrm{PAs} \mathrm{s}^{\circ}$ of ${ }^{\circ} \mathrm{AH}$, $\mathrm{GH}$, and $\mathrm{CH}$ precludes a correlation between the PA values and the order of preference for $\mathrm{AH}, \mathrm{GH}$, and $\mathrm{CH}$ loss.

We next speculated as to whether a nearby negatively ${ }^{\circ}$ charged $^{\circ}$ phosphate ${ }^{\circ}$ might $^{\circ}$ change $^{\circ}$ the ${ }^{\circ}$ relative ${ }^{\circ} \mathrm{PA}$ ordering. While the PAs of the free nucleobases, the corresponding ${ }^{\circ}$ deoxyribose ${ }^{\circ}$ nucleosides, ${ }^{\circ}$ and $^{\circ}$ the ${ }^{\circ}$ mononucleotides where the phosphate moiety is neutral have been calculated, to our knowledge there has been no systematic study of the proton affinity of nucleobases attached to deprotonated, anionic ribose monophosphates $^{\circ}\left[29,{ }^{\circ} 30\right] .{ }^{\circ} \mathrm{In}^{\circ}$ an $^{\circ}$ effort $^{\circ}$ to ${ }^{\circ}$ ascertain ${ }^{\circ}$ whether ${ }^{\circ}$ the proton affinity of a given nucleobase may be influenced by the proximity of a negatively charged phosphate, we calculated the proton affinity of the nucleobase portion of mononucleotides where the phosphate group is both protonated $^{\circ}(\text { neutral })^{\circ}$ and $^{\circ}$ deprotonated $^{\circ}$ (anionic, ${ }^{\circ}$ Table 4). ${ }^{\circ} \mathrm{To}^{\circ}$ minimize ${ }^{\circ}$ the ${ }^{\circ}$ possibility ${ }^{\circ}$ of $^{\circ} \mathrm{a}^{\circ}$ strong ${ }^{\circ}$ gas-phase internal hydrogen bond forming from ${ }^{\circ}$ hearby heteroatom to either the terminal $-\mathrm{OH}$ or the phosphate $-\mathrm{OH}$ groups, the methoxy $\left(-\mathrm{OCH}_{3}\right)$ group was placed at these $^{\circ}$ sites $^{\circ}\left(\text { Figure }^{\circ} 2\right)^{\circ}{ }^{\circ}$ Each $^{\circ}$ nucleobase ${ }^{\circ}$ has ${ }^{\circ}$ several possible protonation sites; we focus on those that have been $^{\circ}$ calculated ${ }^{\circ}$ to ${ }^{\circ}$ have ${ }^{\circ}$ the ${ }^{\circ}$ highest $^{\circ}$ proton ${ }^{\circ}$ affinity ${ }^{\circ}[25]$.

Overall, the calculated proton affinities for the mononucleotide anions are higher than their neutral counterparts; that is, $\mathrm{PA}\left(\mathrm{dBp}^{-}, \mathrm{dpB}^{-}\right) \gg \mathrm{PA}(\mathrm{dBp}, \mathrm{dpB})$. A negative charge on a phosphate therefore appears, perhaps not surprisingly, to enhance the proton affinity of the proximally attached nucleobase. In terms of the PA trends, thymine is the least basic, supporting the idea that $\mathrm{TH}$ should be cleaved least frequently because of its low PA, which we observe experimentally. The PAs of G, C, and A are all fairly close in value and do not correlate with observed preferences for base cleavage. It would seem that additional factors other than PA contribute $^{\circ}$ to $^{\circ}$ the ${ }^{\circ}$ ease $^{\circ}$ of $^{\circ}$ nucleobase ${ }^{\circ}$ cleavage $^{\circ}[9] .{ }^{\circ}$ Our calculations are still of interest, however, in that we have $^{\circ}$ found ${ }^{\circ}$ that $^{\circ}$ nearby ${ }^{\circ}$ deprotonated ${ }^{\circ}$ anionic ${ }^{\circ}$ phosphates enhance the PA of the attached nucleobase. It may therefore be possible that proximal negatively charged phosphates enhance the ease of cleavage of the closest ${ }^{\circ}$ attached ${ }^{\circ}$ nucleobase ${ }^{\circ}[30]$.

CONSTRUCTING CHARGE LOCATION. In an effort to gain insight into the relationship between neutral base loss and charge level, we conducted further MS/MS studies of selected ODNs at both the -2 and -3 charge states ${ }^{\circ}[8]$. Our $^{\circ}$ goal ${ }^{\circ}$ is $^{\circ}$ to ${ }^{\circ}$ identify ${ }^{\circ}$ initial ${ }^{\circ}$ charge ${ }^{\circ}$ locations on the parent ion by examining all the observed (a-B) and $\mathrm{w}$ ions, and their respective charge states. For the Y-series, where $Y=C, G$, or $A$, the observed (a-B) and $\mathrm{w}^{\circ}$ ions $^{\circ}$ are $^{\circ}$ almost $^{\circ}$ identical. $^{\circ}$ Two $^{\circ}$ representative $^{\circ}$ mass spectra $^{\circ}$ resulting $^{\circ}$ from $^{\circ}$ low-energy ${ }^{\circ}$ CID $^{\circ}$ of ${ }^{\circ} 5^{\prime}$ CCAAAAACC $-3^{\prime}\left(Y \text {-series, }{ }^{\circ} \text { where }{ }^{\circ} Y^{\circ}={ }^{\circ} A\right)^{\circ}$ at ${ }^{\circ}$ the ${ }^{\circ}-2^{\circ}$ and $-3^{\circ}$ charge $^{\circ}$ states $^{\circ}$ are $^{\circ}$ shown ${ }^{\circ}$ in ${ }^{\circ}$ Figure $^{\circ} 6^{\circ}$ and ${ }^{\circ}$ Figure $^{\circ} 7$, with ion assignments and sequence reconstructions. Because (a-B) ions are increasingly sequentially numbered from the $5^{\prime}$ to the $3^{\prime}$ end, while the $\mathrm{w}$ ions are numbered from the $3^{\prime}$ to $5^{\prime}$ end, $\left(a_{n}-B_{n}\right)$ and $\mathrm{w}_{(9-n)}$ are a pair of fragments that result from one cleavage that was preceded by $B_{n}$ loss. Assuming that the negative charges are not mobile during the CID process and always ${ }^{\circ}$ reside $^{\circ}$ on $^{\circ}$ the $^{\circ}$ phosphodiester ${ }^{\circ}$ linkages ${ }^{\circ}[15],{ }^{\circ}$ one

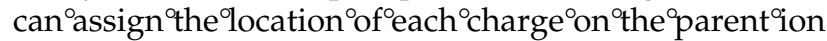
if adequate (a-B) and $w$ ions are observed; we did so for $\left[5^{\prime}-\mathrm{CCAAAAACC}^{\prime}-3^{\prime}\right]^{2-}$ (gray circles on listed sequence, ${ }^{\circ}$ Figure $\left.^{\circ} 6\right) .^{\circ}$ The $^{\circ}$ process $^{\circ}$ for $^{\circ}$ this ${ }^{\circ}$ assignation ${ }^{\circ}$ is fairly straightforward. For the CID of $\left[5^{\prime}-\right.$ CCAAAAACC $\left.-3^{\prime}\right]^{2-}$, the $\left(\mathrm{a}_{8}-\mathrm{C}_{8}\right)^{2-}, \mathrm{w}_{8}^{2-}, \mathrm{w}_{7}^{2-}$, and the complementary $\left(\mathrm{a}_{\mathrm{n}}-\mathrm{B}_{\mathrm{n}}\right)^{-} / \mathrm{w}_{(9-\mathrm{n})}{ }^{-}(n=3$ to 7$)$ ions are observed in the spectra. The appearance of the doubly charged $\left(\mathrm{a}_{8}-\mathrm{C}_{8}\right)$ ion at $\mathrm{m} / \mathrm{z} 1119.8$ and the singly charged $\left(\mathrm{a}_{7}-\mathrm{A}_{7}\right)$ ion at $\mathrm{m} / \mathrm{z} 1927.1$ would imply that before fragmentation, there were two charges on the $\left(\mathrm{a}_{8}-\mathrm{C}_{8}\right)$ portion of the parent ion, but only one charge on the $\left(a_{7}-A_{7}\right)$ portion. The "missing" charge on the $\left(a_{7}-A_{7}\right)$ fragment has only one possible position in the original parent ion, on the phosphate group between $A_{7}$ and $C_{8}$. The presence of the $\mathbf{w}_{2}^{-}$ion $(\mathrm{m} / \mathrm{z} 595.0)$ is also consistent with the charge residing between $\mathrm{A}_{7}$ and $\mathrm{C}_{8}$. The presence of the $\mathbf{w}_{7}^{2-}$ ion $(\mathrm{m} / \mathrm{z} 1079.8)$ and the $\mathbf{w}_{6}^{-}$ion $(\mathrm{m} / \mathrm{z}$ 1847.0) imply that the second charge resided between $\mathrm{C}_{2}$ and $\mathrm{A}_{3}$ on the original parent ion. In addition, the complementary $\left(\mathrm{a}_{\mathrm{n}}-\mathrm{B}_{\mathrm{n}}\right) / \mathrm{w}_{(9-\mathrm{n})}(n=3$ to 7$)$ pairs are all singly charged ions, and no other charge states are observed for these fragments. This also indicates that there should be one charge on each end. The CID spectrum for the $\left[5^{\prime}-\mathrm{CCAAAAACC}-3^{\prime}\right]^{3-}$ ion (charge level $37.5 \%$ ) can be analyzed in the same way to resolve the ${ }^{\circ}$ original $^{\circ}$ charge $^{\circ}$ locations $^{\circ}\left(\right.$ insert $^{\circ}$ Figure $\left.^{\circ} 7\right) .^{\circ}$ The appearance of $\mathbf{w}_{8}^{3-}(\mathrm{m} / \mathrm{z} 816.2), \mathbf{w}_{7}^{2-}(\mathrm{m} / \mathrm{z} 1080.1)$, and $\left(\mathrm{a}_{2}-\mathrm{C}_{2}\right)^{-}(\mathrm{m} / \mathrm{z} 386.0)$ imply that there is one charge 


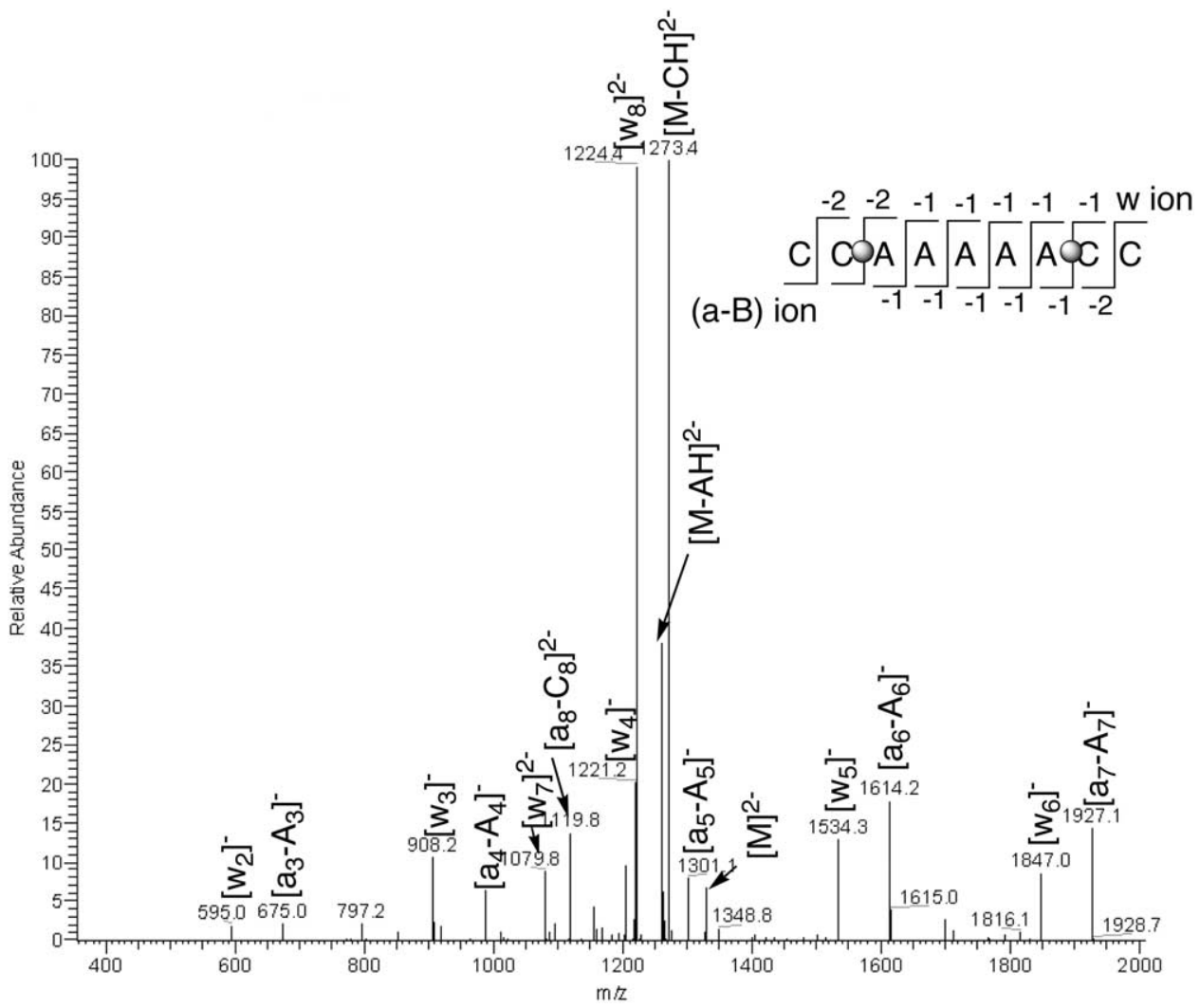

Figure 6. Low-energy CID mass spectrum of the $[\mathrm{M}]^{2-}$ ion of d(CCAAAAACC) at $16 \%$ REA $(0.8 \mathrm{~V})$. Gray circles indicate reconstructed charge locations.

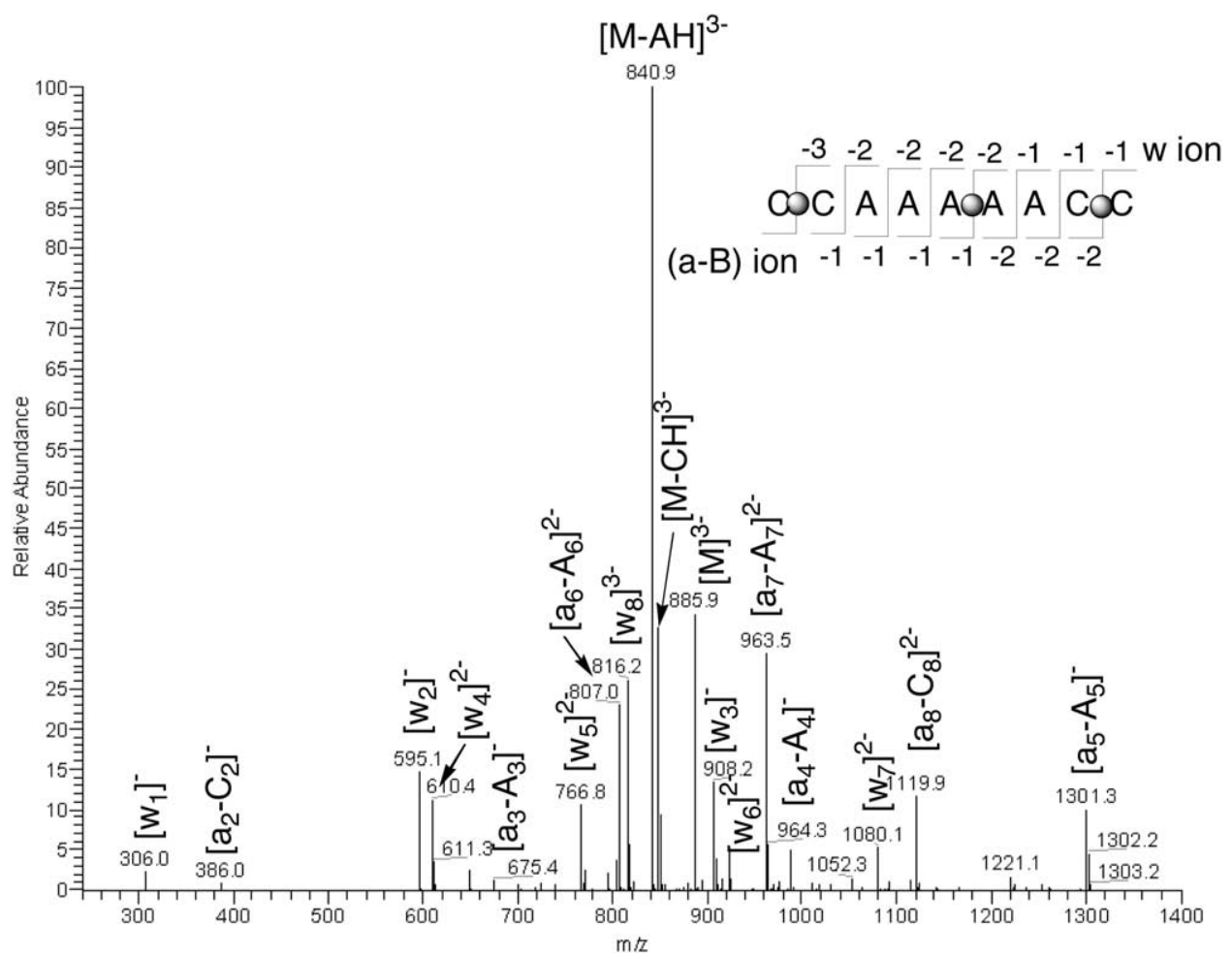

Figure 7. Low-energy CID mass spectrum of the $[\mathrm{M}]^{3-}$ ion of d(CCAAAAACC) at $14 \%$ REA (0.7 V). Gray circles indicate reconstructed charge locations. 


$$
\begin{aligned}
& \text { X-series: } \quad \begin{array}{c}
\text { Column A } \\
(-3 \text { charge state })
\end{array} \\
& \mathrm{X}=\mathrm{G}, \mathrm{C}, \mathrm{A}
\end{aligned}
$$

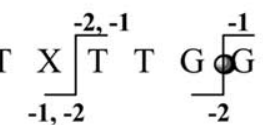

$$
\begin{aligned}
& \mathrm{G} \stackrel{-2}{\mathrm{G}}{ }^{-2} \mathrm{~T} T \\
& \text { Column B } \\
& \text { (-2 charge state) }
\end{aligned}
$$

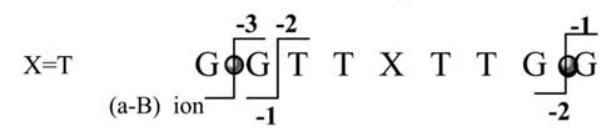

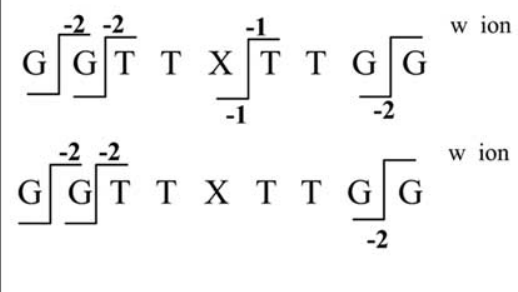

$$
\begin{aligned}
& \text { Y-series: } \\
& \text { ( }-3 \text { charge state) }
\end{aligned}
$$

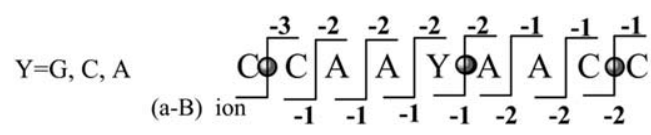

$$
\begin{aligned}
& \mathrm{Y}=\mathrm{T} \quad \underset{\text { (a-B) ion }}{\mathrm{C}} \mathrm{C}]_{-1}^{-3} \mathrm{~A} \int_{-1}^{-2} \mathrm{~A} \underset{-2}{\mathrm{~A}} \underset{-2}{\mathrm{~A}} \underset{-2}{\mathrm{C}} \oint_{-2}^{-1} \\
& \text { (-2 charge state) }
\end{aligned}
$$

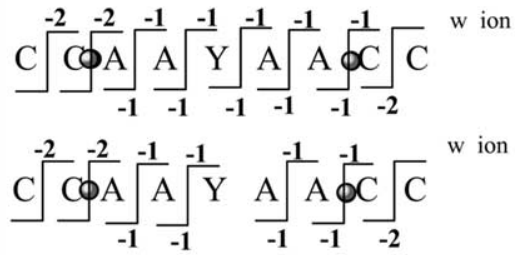

Figure 8. Reconstructed sequences and charge locations for the X-and Y-series ODNs at the -3 (left) and -2 (right) charge states. Gray circles and ovals indicate charge locations. Observed (a-B) and w ions are indicated on each sequence, with the charge state of each fragment labeled as $-1,-2$, or -3 .

between $C_{1}$ and $C_{2}$. The presence of the singly charged $\left(\mathrm{a}_{3}-\mathrm{A}_{3}\right)^{-}(\mathrm{m} / \mathrm{z} 675.4),\left(\mathrm{a}_{4}-\mathrm{A}_{4}\right)^{-}\left(\mathrm{m} / \mathrm{z}\right.$ 988.7), and $\left(\mathrm{a}_{5}-\mathrm{A}_{5}\right)^{-}$ $(\mathrm{m} / \mathrm{z}$ 1301.3) would imply that there should be no charge residing between $C_{2}$ and $A_{4}$ because one charge has already been assigned between $C_{1}$ and $C_{2}$. The appearance of the doubly charged $\left(\mathrm{a}_{6}-\mathrm{A}_{6}\right)^{2-}\left(\mathrm{m} / \mathrm{z}\right.$ 807.0), $\left(\mathrm{a}_{7^{-}}\right.$ $\left.\mathrm{A}_{7}\right)^{2-{ }^{\circ}}\left(\mathrm{m} / \mathrm{z}\right.$ 963.5), and $\left(\mathrm{a}_{8}-\mathrm{C}_{8}\right)^{2-{ }^{\circ}}(\mathrm{m} / \mathrm{z} 1119.9)^{\text {osuggest that }}$ the ${ }^{\circ}$ second ${ }^{\circ}$ charge $^{\circ}$ should ${ }^{\circ}$ be $^{\circ}$ somewhere ${ }^{\circ}$ between ${ }^{\circ} \mathrm{A}_{5}$ and $\mathrm{C}_{8}$. Because the $\mathrm{w}_{4}^{2-}(\mathrm{m} / \mathrm{z}$ 610.4) ion is doubly charged and the $\mathbf{w}_{3-}(\mathrm{m} / \mathrm{z}$ 908.2) ion is singly charged, the second charge should reside between $A_{5}$ and $A_{6}$. Since the total charge number is 3 and the $\mathbf{w}_{1}^{-}(\mathrm{m} / \mathrm{z}$ 306.0), $\mathbf{W}_{2}^{-}(m / z 595.1)$, and $\mathbf{w}_{3}^{-}(m / z$ 908.2) are all singly charged, the third charge only has one possible site, which is between $\mathrm{C}_{8}$ and $\mathrm{C}_{9}$.

The $^{\circ}$ reconstructed ${ }^{\circ}$ sequences ${ }^{\circ}$ for ${ }^{\circ}$ both $^{\circ}$ the ${ }^{\circ} \mathrm{X}^{\circ}$ and Y-series ${ }^{\circ}$ are $^{\circ}$ summarized $^{\circ}$ in $^{\circ}$ Figure $^{\circ} 8^{\circ}\left(\right.$ circles $^{\circ}$ and ${ }^{\circ}$ ovals indicate charge locations). For both the X-and Y-series, all observed (a-B) and $\mathrm{w}$ ions are indicated on the sequences with the charge states labeled as $-1,-2$, or -3 . For the $X$-series $\left(5^{\prime}\right.$-GGTTXTTGG-3'), the charge assignation is not as straightforward as for the Y-series, because ${ }^{\circ} \mathrm{TH}^{\circ}$ is ${ }^{\circ}$ rarely $^{\circ}$ cleaved $^{\circ}$ and $^{\circ}$ the ${ }^{\circ}$ corresponding $(\mathrm{a}-\mathrm{B}) / \mathrm{w}$ ions are not observed, adding an element of uncertainty to the charge location. For the -3 charge state ${ }^{\circ}$ of $^{\circ}$ the ${ }^{\circ} \mathrm{X}$-series ${ }^{\circ}$ (Figure ${ }^{\circ} 8{ }^{\circ}{ }^{\circ}$ Column $\left.{ }^{\circ} \mathrm{A}\right){ }^{\circ}$, two ${ }^{\circ}$ charges are on the terminal phosphates, while the location of the third cannot be pinpointed because of insufficient (a$\mathrm{BH})$ and $\mathrm{w}$ fragments. For the -3 charge state of the Y-series ${ }^{\circ}$ (Figure 8 ; ${ }^{\circ}$ Column $^{\circ} \mathrm{A}$ ), ${ }^{\circ}$ where ${ }^{\circ} \mathrm{Y}=\mathrm{G}$ and $\mathrm{C}$, the charges are found to reside at the same positions as were found for the -3 charged ions of $Y=A$. For $Y=$ $\mathrm{T}\left(5^{\prime}\right.$-CCAATAACC-3'), the complementary $\left(\mathrm{a}_{5}-\mathrm{T}_{5}\right) / \mathrm{w}_{4}$ ion pair is missing due to the lack of TH loss at position 5 , thus, the gray circle is more oval-like, indicating our inability to assign the exact location for the middle charge. However, the two terminal charges can still be clearly reconstructed, and the middle charge is located somewhere between $\mathrm{A}_{4}$ and $\mathrm{A}_{6}$. For the -2 charge state of $^{\circ}$ the ${ }^{\circ} \mathrm{X}$-series ${ }^{\circ}$ (Figure ${ }^{\circ} 8{ }^{\circ}{ }^{\circ}$ Column $\left.^{\circ} \mathrm{B}\right),{ }^{\circ}$ we $^{\circ}$ are $^{\circ}$ unable ${ }^{\circ}$ to locate any exact charge locations due to too few fragments. For all the Y-series ODNs, the location of negative charges on the -2 charge state ions are found to reside on the penultimate phosphate groups of each terminus ${ }^{\circ}\left(\right.$ Figure $^{\circ} 8 ;{ }^{\circ}$ Column $\left.^{\circ} \mathrm{B}\right)$.

To validate our charge site assignation protocol, we also ${ }^{\circ}$ examined ${ }^{\circ}$ all $^{\circ}$ the ${ }^{\circ}$ non- $\mathrm{T}^{\circ}$ rich $^{\circ} \mathrm{ODN}^{\circ}{ }^{\circ}$-mers ${ }^{\circ}$ in ${ }^{\circ}$ Table 3 at the $-3^{\circ}$ and $^{\circ}-2^{\circ}$ charge ${ }^{\circ}$ states. ${ }^{\circ}$ We ${ }^{\circ}$ find ${ }^{\circ}$ the ${ }^{\circ}$ results ${ }^{\circ}$ to be consistent within each charge state. For the -3 charge state, two charges are located on the $5^{\prime}$ - and $3^{\prime}$-terminal phosphates and one resides in the middle of the sequence, in an evenly distributed fashion, presumably minimizing Coulombic repulsions. For the -2 charge state, the two charges are located on the penultimate phosphate groups at each terminus.

We are still left with the mystery of why $\mathrm{BH}$ loss follows the trend $\mathrm{AH}>\mathrm{CH}$ and $\mathrm{AH} \geq \mathrm{GH}$ at the -3 state while terminal $\mathrm{BH}$ loss is most preferred at the -2 state. Our aforementioned PA calculations indicate that a negative charge dramatically enhances the PA of the nearest attached nucleobase, relative to a nucleobase near a neutral phosphate. The corollary to this finding would be that nucleobases adjacent to negatively charged phosphates should have the highest probability of protonation and presumably, cleavage. For the -2 charged $Y$-series, the nucleobases adjacent to negatively charged phosphates are $C_{2}, A_{3}, A_{7}$, and $C_{8}$. For the -3 charged $Y$-series where $Y=G, C$ and $A$ ( $T$ is omitted since its lack of cleavage results in ambiguity of charge location), the nucleobases with negatively charged phosphates are $\mathrm{C}_{1}, \mathrm{C}_{2}, \mathrm{Y}_{5}, \mathrm{~A}_{6}, \mathrm{C}_{8}$, and $\mathrm{C}_{9}$. By our simple arguments, we would expect nearly equivalent $\mathrm{CH}$ and 
AH loss for the -2 state (since an equivalent number of $\mathrm{C}^{\prime} \mathrm{s}$ and A's are adjacent to a negatively charged phosphate) ${ }^{\circ}$ and ${ }^{\circ} \mathrm{CH}$-preferred ${ }^{\circ} \operatorname{loss}^{\circ}$ for $^{\circ}$ the ${ }^{\circ}-3^{\circ}$ state $^{\circ}$ (since more ${ }^{\circ} \mathrm{C}^{\prime} \mathrm{s}^{\circ}$ than ${ }^{\circ} \mathrm{A}^{\prime} \mathrm{s}^{\circ}$ are ${ }^{\circ}$ adjacent ${ }^{\circ} \mathrm{to}^{\circ} \mathrm{a}^{\circ}$ negatively ${ }^{\circ}$ charged phosphate), yet this is not what we observe. We are left with the argument that other factors are at play, most probably related to the secondary and tertiary structure of the oligonucleotide ions, as first proposed by Daneshfar and Klassen [9]. More 9 highly ${ }^{\circ}$ charged ODNanions are $^{\circ}$ more $^{\circ}$ extended $^{\circ}[31]^{\circ}$ and ${ }^{\circ}$ these ${ }^{\circ}$ conformational changes result in different electrostatic and hydrogen bonding interactions between groups along the chain, causing base loss patterns to change. Empirically speaking, at the $37.5 \%$ charge level ( -3 charge state), the trends are $\mathrm{AH}>\mathrm{CH}$ and $\mathrm{AH} \geq \mathrm{GH}$. At the $25 \%$ charge level ( -2 charge state), terminal bases are preferentially cleaved over internal bases.

How do these trends compare with those found in previous studies? McLafferty and coworkers reported a trend of $\mathrm{AH}>\mathrm{GH}>\mathrm{CH}$, with no $\mathrm{TH}$ loss, from a [5'-AAGTCGGTGCTTG] ${ }^{5-}$ ion (charge level 38.5\%) [18]. These ${ }^{9}$ results ${ }^{\circ}$ are $^{\circ}$ consistent $^{\circ} w^{\circ}$ th $^{\circ}$ our $^{\circ}$ preferences ${ }^{\circ}$ at the $37.5^{\circ}{ }^{\circ}$ charge 9 level: ${ }^{\circ} \mathrm{AH}>\mathrm{CH}^{\circ}$ and $^{\circ} \mathrm{AH}{ }^{\circ} \geq{ }^{\circ} \mathrm{GH}$. ${ }^{\circ}$ Different trends for $\mathrm{AH}, \mathrm{GH}$, and $\mathrm{CH}$ loss were observed by Smith and coworkers from two ODN 12-mers (5'CAGTTCGAACTG- $3^{\circ}{ }^{\circ}$ and $^{\circ} 5^{\prime}$-GTCAAGCTTGAC- $3^{\prime}$ ) at the $-5,-4$, and -3 charge states (charge levels of 45,36 , and $27 \%$, respectively) ${ }^{\circ}[17] .^{\circ}$ At ${ }^{\circ}$ charge level $^{\circ}$ of $45 \%,{ }^{\circ} \mathrm{AH}$ is the major base lost, consistent with what we see at $37.5 \%{ }^{\circ}$ charge ${ }^{\circ}$ level. ${ }^{\circ} \mathrm{At}^{\circ} \mathrm{a}^{\circ}{ }^{\circ}$ Charge ${ }^{\circ}$ level ${ }^{\circ}$ of ${ }^{\circ} 36 \%$, the trend is ${ }^{\circ} \mathrm{AH}^{\circ}>{ }^{\circ} \mathrm{CH}^{\circ} \approx{ }^{\circ} \mathrm{GH}^{\circ} \gg{ }^{\circ} \mathrm{TH},{ }^{\circ}$ again ${ }^{\circ}$ consistent ${ }^{\circ}$ with $^{\circ}$ our data $^{\circ}$ at $^{\circ} 37.5 \%{ }^{\circ}{ }^{\circ}$ At $^{\circ}$ charge $^{\circ}$ level ${ }^{\circ}$ of ${ }^{\circ} 27 \%,{ }^{\circ} \mathrm{GH}^{\circ}$ loss $^{\circ}$ is ${ }^{\circ}$ the major dissociation channel; this is consistent with our data at the $25 \%$ charge level insofar as G is a terminal base in Smith's sequences. Williams and coworkers examined a series of doubly deprotonated 7-mers (5'(A) - $^{\prime} 3^{\prime}, 5^{\prime}$-AATTAAT-3', 5'-TTAATTA-3', and 5'-CCGGCCG-3 ${ }^{\prime}$; ${ }^{\circ}$ charge ${ }^{\circ}$ level $\left.{ }^{\circ} 33^{\circ} \%\right)^{\circ}$ and $^{\circ}$ found $^{\circ}$ that $^{\circ}$ at ${ }^{\circ}$ effective

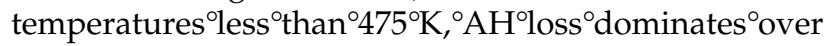
$\mathrm{GH}$ and $\mathrm{CH}$ loss, which is consistent with our results at the ${ }^{\circ} 37.5 \%{ }^{\circ}$ charge ${ }^{\circ}$ level ${ }^{\circ}[5]$.

Our studies focus on oligonucleotides with multiple reactive bases. Two previous experiments focused on systems with a limited number of reactive bases; that is, by using a thymine-rich sequence, these researchers can study specific base loss (since thymine is rarely cleaved). ${ }^{\circ} \mathrm{Wan}^{\circ} \mathrm{and}^{\circ} \mathrm{Gross}^{\circ} \mathrm{concluded}$ the propensity for base loss follows the order $\mathrm{GH}>\mathrm{CH} \approx \mathrm{AH} \gg \mathrm{TH}$ by examining the ease of formation of the (a-BH) ion from $\mathrm{a}^{\circ}$ set $^{\circ}$ of $^{\circ}$ doubly $^{\circ}$ deprotonated $^{\circ}$ T-rich ${ }^{\circ} 8$-mers ${ }^{\circ}\left(5^{\prime}\right.$-TTTXYTTT-3 ${ }^{\prime},{ }^{\circ} X / Y^{\circ}=\mathrm{G}, \mathrm{C}, \mathrm{A}$, or T, charge level 29\%) [13]. Daneshfar ${ }^{\circ}$ and $^{\circ} \mathrm{K}$ lassen ${ }^{\circ}$ also examined a series of thymine-rich strands, focusing on the fragmentation of doubly charged 10-mers of the sequences $\mathrm{XT}_{9}, \mathrm{~T}_{9} \mathrm{X}$, and $\mathrm{T}_{5} \mathrm{XT}_{4}(\mathrm{X}=\mathrm{G}, \mathrm{C}$, or $\mathrm{A}$, charge level $22 \%)$, using BIRD [9]..$^{\circ}$ Over ${ }^{\circ}$ the ${ }^{\circ}$ temperature ${ }^{\circ}$ range ${ }^{\circ}$ Klassen investigated (120 to $190^{\circ} \mathrm{C}$ ), the kinetics for the loss of $\mathrm{AH}, \mathrm{GH}$, and $\mathrm{CH}$ follow the trend $\mathrm{AH} \approx \mathrm{GH}>\mathrm{CH}$. Comparison of these two sets of data to ours and earlier results at comparable charge levels do not show agreement, but we believe that comparison is complicated by the thymine-rich sequences.

In general, we find that for nonthymine-rich sequences studied both previously and herein, when the charge level of the parent ODN ion is greater than 33\%, $\mathrm{AH}$ loss is preferred over $\mathrm{GH}$ and $\mathrm{CH}$ loss. For charge levels below $30 \%$, there are not enough data to make generalizations; we observe that terminal bases are preferentially cleaved.

\section{Conclusions}

The overall charge state distribution of two series of deprotonated ODN 9-mers (5'-GGTTXTTGG-3' and 5'CCAAYAACC- $3^{\prime}, X / Y=G, C, A$, or T) was studied in detail. The distribution of charge states $(-2$ to -6$)$ is similar for both the X- and Y-series, with the most abundant charge state being -4 . Apparently, the $X$-series prefers higher charge states $(-6$ and -5$)$ than does the Y-series. Our calculated acidities of deoxynucleoside $5^{\prime}$ - and $3^{\prime}$-monophosphates indicate that thymidine monophosphate is the most acidic of the mononucleotides, which may account for why the T-rich X-series tends to bear more charges than does the non T-rich Y-series.

The fragmentation of these ODN 9-mers at each charge state under gentle collision conditions is also reported. The "charge level" of the ODN seems to play a significant role in determining the most dominant fragmentation channels. When the charge level of a parent ODN ion is greater than $50 \%$, loss of the nucleobase as an anion $\left(\mathrm{B}^{-}\right)$dominates, with the base loss trend being $\mathrm{A}^{-} \gg \mathrm{G}^{-} \approx \mathrm{T}^{-}>\mathrm{C}^{-}$for all the ODN sequences studied, which is consistent with previous studies. These preferences in anionic base loss do not correlate strictly with the acidity of the corresponding conjugate acid $\mathrm{BH}$; another possible factor dictating the preferences may be the stability of the nucleobase anions. This latter hypothesis is supported by resonance structure arguments as well as electrostatic potential calculations.

At charge levels of 37.5 and $25.0 \%$, the bases are lost exclusively as neutrals (BH), with no detectable thymine loss. At a charge level of $37.5 \%$, the loss of $\mathrm{AH}$ is preferred over the loss of $\mathrm{GH}$ and $\mathrm{CH}$, consistent with earlier data. However, at a charge level of $25.0 \%$, terminal base loss is preferred over that of internal bases. Reconstruction of the ODN sequences from (a$\mathrm{BH})$ and $\mathrm{w}$ ions allows the assignation of charge locations on the parent ODN ions. For the -3 charge state, two charges reside on the terminal bases while the third is in the middle. For the -2 charge state, one charge each resides on the base penultimate to the terminal site. We hypothesize that a negatively charged phosphate enhances loss of a proximal nucleobase by increasing the nucleobase's proton affinity, which is further supported by our PA calculations. This effect alone, however, as modeled by a mononucleotide, does not 
explain the trends we see: that is, the bases located in sequence next to a negatively charged phosphate are not necessarily preferentially cleaved. However, in longer oligonucleotides, folding could result in negatively charged phosphates being proximal to nucleobases that are not nearby in sequence; we therefore conclude that tertiary structure must play a role in influencing base loss trends. Comparison of our data to previous work shows a consistent trend of AH-preferred loss for charge levels greater than $33 \%$, given that the sequences are not thymine-rich. For charge levels less than 30\%, there are not enough data to make generalizations; we observe that terminal bases are preferentially cleaved, regardless of sequence. Future studies will further hone these trends by systematically examining base loss versus charge level. Also, molecular dynamics calculations that will allow us to examine the tertiary structure of these ODNs, to ascertain which nucleobases are proximal to negatively charged phosphates, will aid in the understanding of the influence of conformation on base loss.

\section{Acknowledgments}

The authors thank the National Science Foundation (CHE0092215), the Alfred P. Sloan Foundation, and the Rutgers Busch Grant Program for support, and the National Center for Supercomputing Applications for computational resources. They are grateful to John Kerrigan and F. Sedinam Amegayibor for helpful discussions.

\section{References}

1. McLuckey, S. A.; Habibi-Goudarzi, S. Decompositions of Multiply Charged Oligonucleotide Anions. J. Am. Chem. Soc. 1993, 115, 12085-12095.

2. McLuckey, S. A.; Vaidyanathan, G.; Habibi-Goudarzi, S. Charged versus Neutral Nucleobase Loss from Multiply Charged Oligonucleotide Anions. J. Mass Spectrom. 1995, 30, 1222-1229.

3. Bartlett, M. G.; McCloskey, J. A.; Manalili, S.; Griffey, R. H. The Effect of Backbone Charge on the Collision-Induced Dissociation of Oligonucleotides. J. Mass Spectrom. 1996, 31, 12771283.

4. McLuckey, S. A.; Vaidyanathan, G. Charge State Effects in the Decompositions of Single-Nucleobase Oligonucleotide Polyanions. Int. J. Mass Spectrom. 1997, 162, 1-16.

5. Klassen, J. S.; Schnier, P. D.; Williams, E. R. Blackbody Infrared Radiative Dissociation of Oligonucleotide Anions. J. Am. Soc. Mass Spectrom. 1998, 9, 1117-1124.

6. Nordhoff, E.; Karas, M.; Cramer, R.; Hahner, S.; Hillenkamp, F.; Kirpekar, F.; Lezius, A.; Muth, J.; Meier, C.; Engels, J. W. Direct Mass Spectrometric Sequencing of Low-Picomole Amounts of Oligodeoxynucleotides with up to 21 Bases by Matrix-Assisted Laser Desorption/Ionization Mass Spectrometry. J. Mass Spectrom. 1995, 30, 99-112.

7. Wang, Z.; Wan, K. X.; Ramanathan, R.; Taylor, J. S.; Gross, M. L. Structure and Fragmentation Mechanisms of Isomeric T-Rich Oligodeoxynucleotides: A Comparison of Four Tandem Mass Spectrometric Methods. J. Am. Soc. Mass Spectrom. 1998, 9, 683-691.

8. Favre, A.; Gonnet, F.; Tabet, J.-C.Location of the Negative Charge(s) on the Backbone of Single-Stranded Deoxyribonu- cleic Acid in the Gas Phase. Eur. J. Mass Spectrom. 2000, 6 389-396.

9. Daneshfar, R.; Klassen, J. S. Arrhenius Activation Parameters for the Loss of Neutral Nucleobases from Deprotonated Oligonucleotide Anions in the Gas Phase. J. Am. Soc. Mass Spectrom. 2004, 15, 55-64.

10. Zhu, L.; Parr, G. R.; Fitzgerald, M. C.; Nelson, C. M.; Smith, L. M. Oligodeoxynucleotide Fragmentation in MALDI/TOF Mass Spectrometry Using 355-nm Radiation. J. Am. Chem. Soc. 1995, 117, 6048-6056.

11. Krause, J.; Scalf, M.; Smith, L. M. High Resolution Characterization of DNA Fragment Ions Produced by Ultraviolet Matrix-Assisted Laser Desorption/Ionization Using Linear and Reflecting Time-of-Flight Mass Spectrometry. J. Am. Soc. Mass Spectrom. 1999, 10, 423-429.

12. Christian, N. P.; Reilly, J. P.; Mokler, V. R.; Wincott, F. E.; Ellington, A. D. Elucidation of the Initial Step of Oligonucleotide Fragmentation in Matrix-Assisted Laser Desorption/ Ionization Using Modified Nucleic Acids. J. Am. Soc. Mass Spectrom. 2001, 12, 744-753.

13. Wan, K. X.; Gross, M. L. Fragmentation Mechanisms of Oligodeoxynucleotides: Effects of Replacing Phosphates with Methylphosphonates and Thymines with Other Bases in TRich Sequences. J. Am. Soc. Mass Spectrom. 2001, 12, 580-589.

14. Gross, J.; Hillenkamp, F.; Wan, K. X.; Gross, M. L. Metastable Decay of Negatively Charged Oligodeoxynucleotides Analyzed with Ultraviolet Matrix-Assisted Laser Desorption/ Ionization Post-Source Decay and Deuterium Exchange. J. Am. Soc. Mass Spectrom. 2001, 12, 180-192.

15. Rodgers, M. T.; Campbell, S.; Marzluff, E. M.; Beauchamp, J. L. Low-Energy Collision-Induced Dissociation of Deprotonated Dinucleotides: Determination of the Energetically Favored Dissociation Pathways and the Relative Acidities of the $\mathrm{Nu}-$ cleic Acid Bases. Int. J. Mass Spectrom. Ion Processes 1994, 137, 121-149.

16. Wu, J.; McLuckey, S. A. Gas-Phase Fragmentation of Oligonucleotide Ions. Int. J. Mass Spectrom. 2004, 237, 197-241.

17. Luo, H.; Lipton, M. S.; Smith, R. D. Charge Effects for Differentiation of Oligodeoxynucleotide Isomers Containing 8-oxo-dG Residues. J. Am. Soc. Mass Spectrom. 2002, 13, 195199.

18. Little, D. P.; Aaserud, D. J.; Valaskovic, G. A.; McLafferty, F. W. Sequence Information from 42-108-mer DNAs (Complete for a 50-mer) by Tandem Mass Spectrometry. J. Am. Chem. Soc. 1996, 118, 9352-9359.

19. Dewar, M. J.-S.; Zoebisch, E. G.; Healy, E. F.; Stewart, J. J.-P. AM1: A New General Purpose Quantum Mechanical Molecular Model. J. Am. Chem. Soc. 1985, 107, 3902-3909.

20. Binkley, J. S.; Pople, J. A.; Hehre, W. J. Self-Consistent Molecular Orbital Methods. 21. Small Split-Valence Basis Sets for First-Row Elements. J. Am. Chem. Soc. 1980, 102, 939-947.

21. (a) Frisch, M. J.; Trucks, G. W.; Schlegel, H. B.; Scuseria, G. E.; Robb, M. A.; Cheeseman, J. R.; Zakrzewski, V. G.; Montgomery, J. A.; Stratmann, R. E.; Burant, J. C.; Dapprich, S.; Millam, J. M.; Daniels, A. D.; Kudin, K. N.; Strain, M. C.; Farkas, O.; Tomasi, J.; Barone, V.; Cossi, M.; Cammi, R.; Mennucci, B.; Pomelli, C.; Adamo, C.; Clifford, S.; Ochterski, J.; Petersson, G. A.; Ayala, P. Y.; Cui, Q.; Morokuma, K.; Malick, D. K.; Rabuck, A. D.; Raghavachari, K.; Foresman, J. B.; Cioslowski, J.; Oritz, J. V.; Stefanov, B. B.; Liu, G.; Lisashenko, A.; Piskorz, O.; Komaromi, I.; Gomperts, R.; Martin, R. L.; Fox, D. J.; Keith, T.; Al-Laham, M. A.; Peng, C. Y.; Nanayakkara, A.; Gonzalez, C.; Challacombe, M.; Grill, P. M. W.; Johnson, B. G.; Chen, W.; Wong, M. W.; Andres, J. L.; Gonzales, C.; Head-Gordon, M.; Replogle, E. S.; Pople, J. A.; Gaussian 98; Gaussian, Inc.: Pittsburgh, PA, 1998. (b) Frisch, M. J.; Trucks, G. W.; Schlegel, H. B.; Scuseria, G. E.; Robb, M. A.; Cheeseman, J. R.; Mont- 
gomery, J. A., Jr.; Vreven, T.; Kudin, K. N.; Burant, J. C.; Millam, J. M.; Iyengar, S. S.; Tomasi, J.; Barone, V.; Mennucci, B.; Cossi, M.; Scalmani, G.; Rega, N.; Petersson, G. A.; Nakatsuji, H.; Hada, M.; Ehara, M.; Toyota, K.; Fukuda, R.; Hasegawa, J.; Ishida, M.; Nakajima, T.; Honda, Y.; Kitao. O.; Nakai, H.; Klene, M.; Li, X.; Knox, J. E.; Hratchian, H. P.; Cross, J. B.; Bakken, V.; Adamo, C.; Jaramillo, J.; Gomperts, R.; Stratmann, R. E.; Yazyev, O.; Austin, A. J.; Cammi, R.; Pomelli, C.; Ochterski, J. W.; Ayala, P. Y.; Morokuma, K.; Voth, G. A.; Salvador, P.; Dannenberg, J. J.; Zakrzewski, V. G.; Dapprich, S.; Daniels, A. D.; Strain, M. C.; Farkas, O.; Malick, D. K.; Rabuck, A. D.; Raghavachari, K.; Foresman, J. B.; Ortiz, J. V.; Cui, Q.; Baboul, A. G.; Clifford, S.; Cioslowski, J.; Stefanov, B. B.; Liu, G.; Liashenko, A.; Piskorz, P.; Komaromi, I.; Martin, R. L.; Fox, D. J.; Keith, T.; Al-Laham, M. A.; Peng, C. Y.; Nanayakkara, A.; Challacombe, M.; Gill, P. M. W.; Johnson, B.; Chen, W.; Wong, M. W.; Gonzalez, C.; Pople, J. A. Gaussian 03; Gaussian, Inc.: Wallingford, CT, 2004; (c) Breneman, C. M.; Wiberg, K. B. Determining Atom-Centered Monopoles from Molecular Electrostatic Potentials. The Need for High Sampling Density in Formamide Conformational Analysis. J. Comput. Chem. 1990, 11, 361-373.

22. (a) Dewar, M. J.-S.; Dieter, K. M. Evaluation of AM1 Calculated Proton Affinities and Deprotonation Enthalpies. J. Am. Chem. Soc. 1986, 108, 8075-8086; (b) NIST Chemistry WebBook, NIST Standard Reference Database Number 69, March 2003; Mallard, W. G.; Linstrom, P. J., Eds.; National Institute of Standards and Technology: Gaithersburg, MD 20899, 2003; Vol. http://webbook.nist.gov

23. (a) Strittmatter, E. F.; Schnier, P. D.; Klassen, J. S.; Williams, E. R. Dissociation Energies of Deoxyribose Nucleotide Dimer Anions Measured Using Blackbody Infrared Radiative Dissociation. J. Am. Soc. Mass Spectrom. 1999, 10, 1095-1104; (b) Schnier, P. D.; Klassen, J. S.; Strittmatter, E. F.; Williams, E. R. Activation Energies for Dissociation of Double Strand Oligonucleotide Anions: Evidence for Watson-Crick Base Pairing in Vacuo. J. Am. Chem. Soc. 1998, 120, 9605-9613.
24. Gabelica, V.; DePauw, E. Collision-Induced Dissociation of 16-mer DNA Duplexes with Various Sequences: Evidence for Conservation of the Double Helix Conformation in the Gas Phase. Int. J. Mass Spectrom. 2002, 219, 151-159.

25. Chandra, A. K.; Nguyen, M. T.; Uchimaru, T.; ZeegersHuyskens, T. Protonation and Deprotonation Enthalpies of Guanine and Adenine and Implications for the Structure and Energy of Their Complexes with Water: Comparison with Uracil, Thymine, and Cytosine. J. Phys. Chem. A 1999, 103, 8853-8860.

26. Del Bene, J. E. Molecular Orbital Study of the Protonation of DNA Bases. J. Phys. Chem. 1983, 87, 367-371.

27. Russo, N.; Toscano, M.; Grand, A.; Jolibois, F. Protonation of Thymine, Cytosine, Adenine, and Guanine DNA Nucleic Acid Bases: Theoretical Investigation into the Framework of Density Functional Theory. J. Comput. Chem. 1998, 19, 989-1000.

28. Podolyan, Y.; Gorb, L.; Leszczynski, J. Protonation of Nucleic Acid Bases. A Comprehensive Post-Hartree-Fock Study of the Energetics and Proton Affinities. J. Phys. Chem. A 2000, 104, $7346-7352$.

29. Greco, F.; Liguori, A.; Sindona, G.; Uccella, N. Gas-Phase Proton Affinity of Deoxyribonucleosides and Related Nucleobases by Fast Atom Bombardment Tandem Mass Spectrometry. J. Am. Chem. Soc. 1990, 112, 9092-9096.

30. (a) Green-Church, K. B.; Limbach, P. A. Mononucleotide Gas-Phase Proton Affinities as Determined by the Kinetic Method. J. Am. Soc. Mass Spectrom. 2000, 11, 24-32; (b) HabibiGoudarzi, S.; McLuckey, S. A. Ion Trap Collisional Activation of the Deprotonated Deoxymononucleoside and Deoxydinucleoside Monophosphates. J. Am. Soc. Mass Spectrom. 1995, 6, 102-113.

31. (a) Hoaglund, C. S.; Liu, Y.; Ellington, A. D.; Pagel, M.; Clemmer, D. E. Gas-Phase DNA: Oligothymidine Ion Conformers. J. Am. Chem. Soc. 1997, 119, 9051-9052; (b) Moradian, A.; Scalf, M.; Westphall, M. S.; Smith, L. M.; Douglas, D. J. Collision Cross Sections of Gas Phase DNA Ions. Int. J. Mass Spectrom. 2002, 219, 161-170. 